\title{
Nano-Based Systems and Biomacromolecules as Carriers for Metallodrugs in Anticancer Therapy
}

\author{
Mina Poursharifi ${ }^{1,2}$, Marek T. Wlodarczyk ${ }^{1,3}$ and Aneta J. Mieszawska 1,2,3,* \\ 1 Department of Chemistry, Brooklyn College, The City University of New York, 2900 Bedford Avenue, \\ Brooklyn, NY 11210, USA; mina.poursharifi@brooklyn.cuny.edu (M.P.); \\ marekw@brooklyn.cuny.edu (M.T.W.) \\ 2 Ph.D. Program in Biochemistry, The Graduate Center of the City University of New York, New York, \\ NY 10016, USA \\ 3 Ph.D. Program in Chemistry, The Graduate Center of the City University of New York, New York, \\ NY 10016, USA \\ * Correspondence: aneta.mieszawska@brooklyn.cuny.edu; Tel.: +1-718-951-5000 (ext. 2839)
}

Received: 1 November 2018; Accepted: 11 December 2018; Published: 20 December 2018

\begin{abstract}
Since the discovery of cisplatin and its potency in anticancer therapy, the development of metallodrugs has been an active area of research. The large choice of transition metals, oxidation states, coordinating ligands, and different geometries, allows for the design of metal-based agents with unique mechanisms of action. Many metallodrugs, such as titanium, ruthenium, gallium, tin, gold, and copper-based complexes have been found to have anticancer activities. However, biological application of these agents necessitates aqueous solubility and low systemic toxicity. This minireview highlights the emerging strategies to facilitate the in vivo application of metallodrugs, aimed at enhancing their solubility and bioavailability, as well as improving their delivery to tumor tissues. The focus is on encapsulating the metal-based complexes into nanocarriers or coupling to biomacromolecules, generating efficacious anticancer therapies. The delivery systems for complexes of platinum, ruthenium, copper, and iron are discussed with most recent examples.
\end{abstract}

Keywords: metallodrugs; nanoparticles; dendrimers; nanotubes; liposomes; biomacromolecules; encapsulation; targeting; micelles

\section{Introduction}

Cisplatin was the first Food and Drug Administration (FDA)-approved metallodrug for the treatment of solid tumors. Cisplatin, or cis-diamminedichloroplatinum (II), is a square planar coordination complex with two chlorine and two amine ligands in cis configuration. The cytotoxic effects of cisplatin originate from the formation of active cis- $\left[\mathrm{Pt}\left(\mathrm{NH}_{3}\right)_{2}\left(\mathrm{H}_{2} \mathrm{O}\right)_{2}\right]^{2+}$ species that bind to nuclear DNA distorting the helical structure, and interfere with DNA replication and transcription inducing cancer cell apoptosis [1,2]. However, the major limitation of cisplatin is the formation of active species in the systemic circulation. The fast exchange of chloride ligands to water leads to high systemic toxicity and limits the clinical dose of the drug [3]. Therefore, often sub-therapeutic concentrations of cisplatin reaching cancer cells leads to minor DNA damage, DNA repair, and eventually might lead to the growth of resistant cells. Developing platinum-resistance is a major problem in cisplatin-based therapy $[4,5]$. Carboplatin and oxaliplatin are second-generation platinum complexes approved by the FDA for use as anticancer drugs. They are characterized with lower toxicity profiles, broader spectrum of action, and overcoming resistance in some types of tumors. However, analogous to cisplatin mechanism of action hampers elimination of all problems associated with $\mathrm{Pt}(\mathrm{II})$ therapy. Therefore "trans" geometries [6-9], polynuclear [10-14], or platinum (IV) prodrugs [15,16] have been 
explored as possible alternatives, but none have yet entered the clinic. Importantly, high efficacy of platinum paved the way for the development of other transition metal complexes, many with outstanding cytotoxic properties against cancer cells.

Transition metals form complexes of multiple geometries based on the number of coordination sites, offering a stereoisomeric diversity higher than carbon. In addition, a synthesis of metallodrugs requires fewer steps when compared to organic compounds. This is accompanied by a myriad choice of coordinating ligands [17] facilitating fine-tuning the properties of metal-based complexes [17,18]. The octahedral titanium species cis-diethoxy-bis(1-phenylbutane-1,3-dionato)titanium(IV) [(bzac) 2 $\mathrm{Ti}(\mathrm{OEt})_{2}$ ] (budotitane), was the first non-Pt(II) metal compound that reached clinical trials [19]. Following this, ruthenium-based complexes were explored showing fewer side effects when compared to platinum-based agents and activity against Pt-resistant cancers [20-22]. Two ruthenium derivates, imidazolium trans-DMSO-imidazole-tetrachlororuthenate (NAMI-A) and imidazolium trans-[tetrachlorido(DMSO)(1H-imidazole)ruthenate(III)] (KP-1019), have been tested in clinical trials [22,23]. KP-1019 showed efficacy towards primary tumors, such as colon cancer, without triggering systemic toxicity, while NAMI-A was not cytotoxic but demonstrated activity against metastases. Moreover, NKP-1339 (the sodium salt analogue of KP1019, sodium trans-[tetrachloridobis(1H-indazole)ruthenate(III)]) has successfully completed a phase I clinical trial [24]. NKP-1339 is $\mathrm{Ru}(\mathrm{III})$ that binds to serum proteins albumin and transferrin, which transport and deliver the metallodrug to the tumor tissue. Once inside endosomes, NKP-1339 reduces to Ru(II). Recently, new designs of ruthenium complexes are emerging that include $\mathrm{Ru}\left(\eta^{5}-\mathrm{C}_{5} \mathrm{H}_{5}\right)$ core. This class of $\mathrm{Ru}(\mathrm{II})$ compounds demonstrates enhanced selectivity and effectiveness, for example ruthenium pyridocarbazole (DW1/2) showed inhibition of protein kinase in vitro [22,25,26]. Other transition metal complexes include redox-active mono(thiosemicarbazone) copper compounds [27-29], nucleic acid-targeting gold(I) complex auranofin [30], or osmium(II) arene complexes that act on mitochondria [31]. Figure 1 shows a few examples of metallodrugs, including platinum, ruthenium, gallium, and titanium complexes that were found to have anti-cancer activities $[32,33]$.
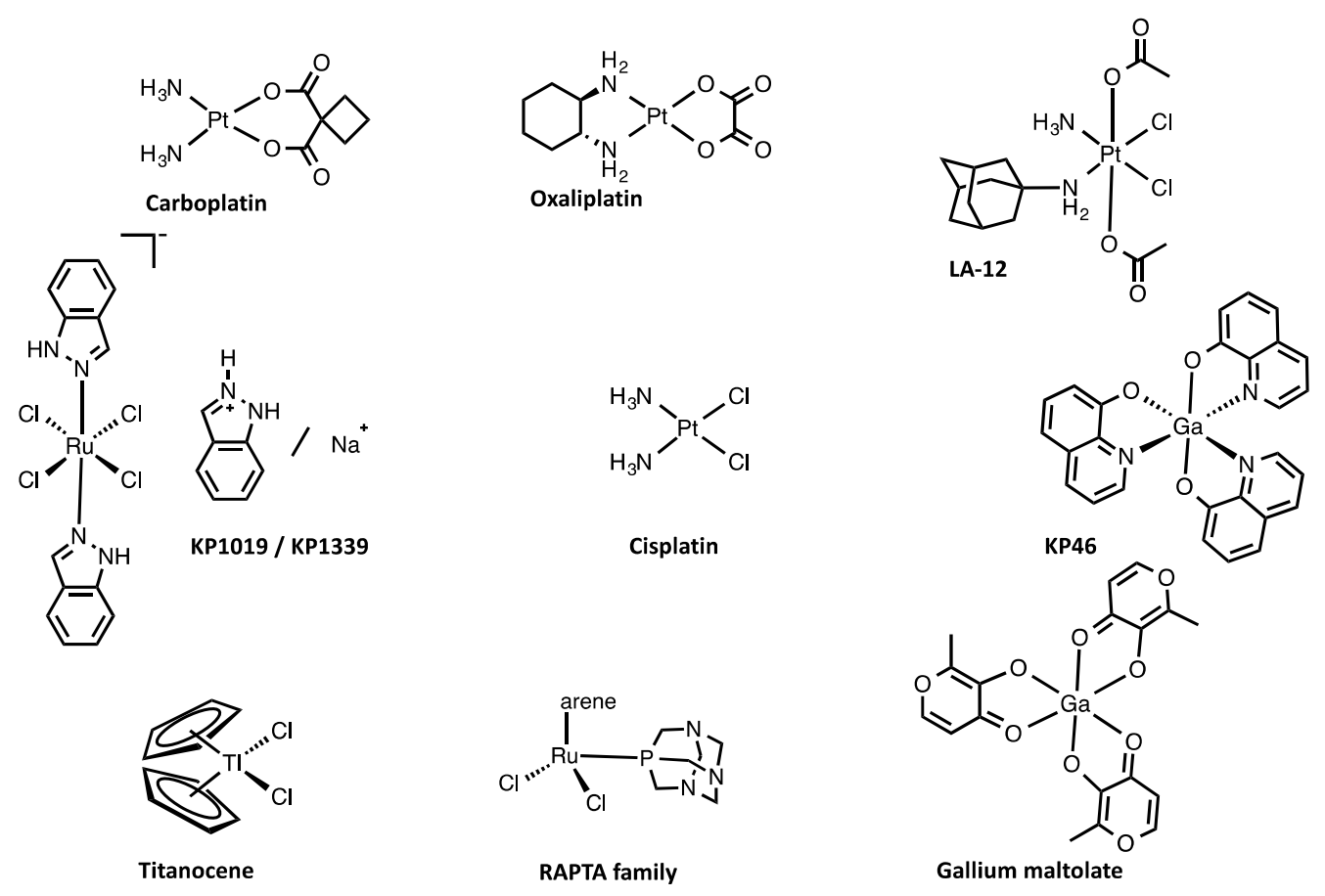

Figure 1. Chemical structures of representative $\mathrm{Pt}, \mathrm{Ru}, \mathrm{Ti}$, and $\mathrm{Ga}$ anticancer drugs.

However, major challenges in the clinical application of metallodrugs, when delivered via conventional intravenous methods, include limited aqueous solubility and short in vivo 
half-lives, resulting in inadequate bioavailability and low accumulation in the tumors. Therefore, many approaches have been proposed to address these limitations, and the main strategies focus on exploring nanotechnology-based systems $[34,35]$. This minireview discusses the examples of synthetic nanoparticles as well as biological carriers used to increase the solubility, reduce the systemic toxicity, increase cancer-cell delivery, or achieve cancer-specific targeting of metallodrugs.

\section{Synthetic Nanocarriers}

The important advantages of nano-based systems for drug delivery applications are high stability, loading capacity, possibility to incorporate hydrophobic or highly toxic drug molecules, and, depending on the core material used, achieving controlled or sustained drug release. This can sharply improve the solubility and bioavailability of the drugs, as well as their pharmacokinetics, while reducing the side effects associated with therapy [36,37]. The nanoparticles can accumulate in the tumor through the enhanced permeability and retention (EPR) effect [38]. In EPR the nanoparticles extravasate through the impaired tumor vasculature, and the lack of appropriate lymphatic drainage leads to their prolonged retention in the tumor tissue. The degree of nanoparticle accumulation in the tumor via EPR depends on the tumor's type and size. The most pronounced EPR effect was observed in pancreatic, colon, breast, and stomach cancers. Also, a higher accumulation of nanoparticles was found in larger tumors [39].

In addition, the versatility of nanoparticle technologies and coating strategies, allows the design of nanoparticle systems capable of cancer cell recognition and selective tumor targeting [40-42]. The advantages of nanocarriers heighten the drug payload within the tumor, thereby improving the therapeutic outcomes. Table 1 summarizes the nanocarrier-based systems for metallodrug delivery that have entered clinical trials.

Table 1. Representative metallodrug delivery systems that have entered clinical trials.

\begin{tabular}{cccccc}
\hline $\begin{array}{c}\text { Delivery } \\
\text { System }\end{array}$ & Active Drug & Formulation & Clinical Status & Tumor Target & Identifier \\
\hline \multirow{2}{*}{$\begin{array}{c}\text { Polymeric } \\
\text { nanoparticles }\end{array}$} & oxaliplatin & AP5346 & Phase II & $\begin{array}{c}\text { Head and Neck } \\
\text { cancer }\end{array}$ & NCT00415298 \\
\cline { 2 - 6 } & oxaliplatin & NC-4016 & Phase I & Colorectal cancer & NCT03168035 \\
\cline { 2 - 6 } & cisplatin & NC-6004 & Phase III & Pancreatic cancer & NCT03109158 \\
\cline { 2 - 6 } Liposome & cisplatin & Lipoplatin & Phase I & Lung cancer & NCT02702700 \\
\cline { 2 - 6 } & oxaliplatin & SPI-077 & Phase I, II & $\begin{array}{c}\text { Ovarian, Breast and } \\
\text { Skin cancer }\end{array}$ & NCT01861496 NCT00004083 \\
\hline $\begin{array}{c}\text { Inorganic } \\
\text { Nanoparticles }\end{array}$ & iron oxide & Ferumoxytol & Early Phase I & Advanced & Gastrointestinal \\
cancer & NCT00964080 \\
\hline
\end{tabular}

Data are gathered from www.clinicaltrials.gov.

\subsection{Liposomes}

Liposomes, discovered in 1960s, are one of the first nanosized vehicles used in drug delivery applications. They are spherical vesicles having an aqueous core surrounded by lipid bilayers, a similar morphology to cellular membranes [43]. Liposomes are ideal to encapsulate hydrophilic drugs in an aqueous core, but the hydrophobic therapeutics can also be entrapped within a lipid bilayer. Liposomes are considered one of the most successful drug delivery vehicles to date [44], with several formulations approved by the FDA for anticancer therapy and available in the clinic [43,45].

The liposomal formulations of cisplatin have been the most studied including LiPlaCis, SPI-77, L-NDDP, or lipoplatin [46,47]. Lipoplatin has successfully completed Phase I, Phase II, and Phase III 
human clinical trials. It is a liposome with diameter of $\sim 110 \mathrm{~nm}$ with long in vivo half-life of $\sim 120 \mathrm{~h}$, and was found to effectively accumulate into tumors, while reducing major toxicities associated with cisplatin [48,49]. Tumoral accumulations with up to ten to 200 -fold increase versus normal tissue were reported $[48,49]$. However, the liposomal formulations did not enhance the clinical efficacy of cisplatin, possibly due to inadequate release of the drug in the tumor [50].

The liposomal formulations of $\mathrm{Ru}$ have also been proposed [51,52] Shen et al. demonstrated encapsulation of ruthenium polypirydine complex $\left[\mathrm{Ru}(\mathrm{phen})_{2} \mathrm{dppz}\right]\left(\mathrm{ClO}_{4}\right)_{2}$ in a liposome carrier (Lipo-Ru), composed of dipalmitoylphosphatidylcholine (DPPC), cholesterol, and distearoylphosphatidylethanolamine (DSPE)-PEG (polyethylene glycol). The schematic of the Lipo-Ru is presented in Figure 2A. The presence of dipyridophenazine (dppz) ligand in the complex served as a "light switch" that emitted when nitrogen atoms of dppz were exposed to the hydrophobic environment of the lipid bilayer [51]. Lipo-Ru was an example of a theranostic system, where drug delivery, as well as imaging studies, can be accomplished using a single platform [53]. The fluorescent properties of the nanocarrier were demonstrated using confocal imaging of cells incubated with Lipo-Ru (Figure 2B). The average diameter of Lipo-Ru was $82.53 \pm 2.66 \mathrm{~nm}$ with Ru loading of $4 \%$ [51]. The liposomes were stable under physiological conditions and biologically active. The in vitro studies using triple negative breast cancer cells demonstrated high cytotoxicity of Lipo-Ru and low $\mathrm{IC}_{50}$ value of $4 \mu \mathrm{M}$.

A

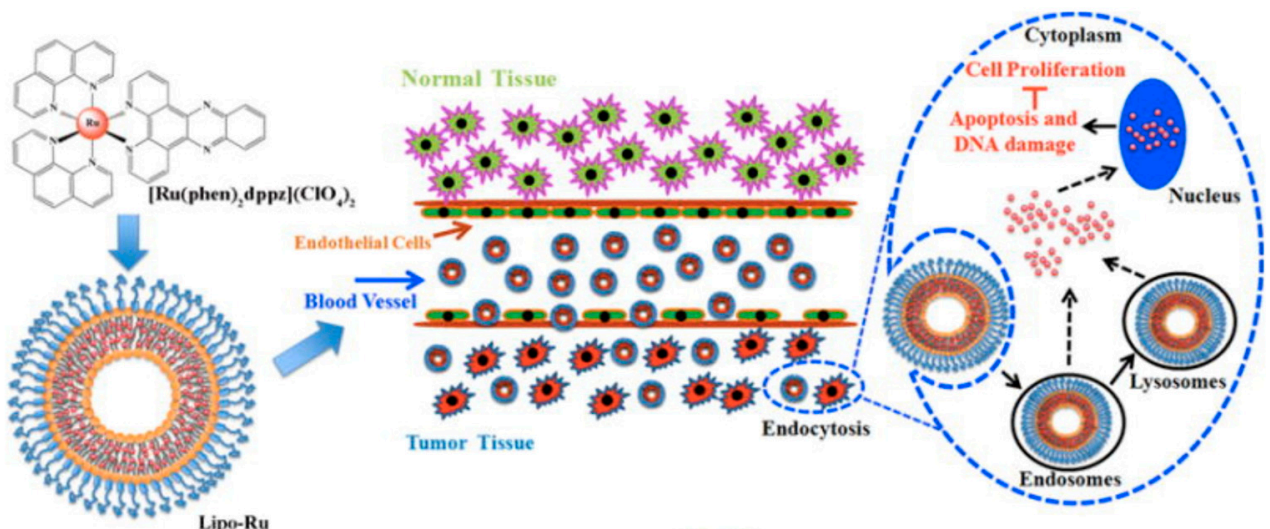

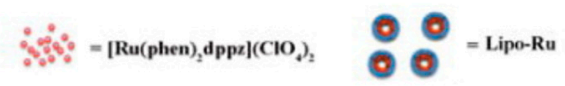

B
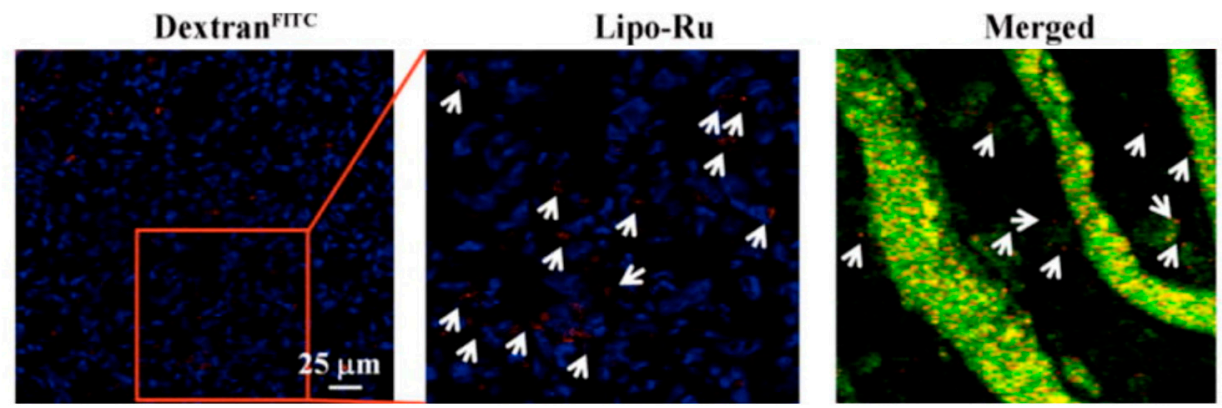

Figure 2. (A) Schematic Representation of Lipo-Ru liposomes, and (B) confocal microscopy images of tumors $2 \mathrm{~h}$ post injection of Lipo-Ru. Lipo-Ru particles are shown in red and highlighted with white arrows. Nuclei are stained in blue with DAPI. Reprinted with permission from reference [51].

\subsection{Micelles}

Micelles are simple nanostructures formed from amphiphilic molecules, they range in size between 5 and $100 \mathrm{~nm}$, and are considered to be suitable for drug delivery applications [54]. Micelles are spherical ellipsoid systems that self-assemble in an aqueous environment to form a hydrophobic monolayer in the core and a polar surface. Micelles disintegrate slowly upon the interaction of polar 
groups with water, which leads to pore formation within the hydrophobic part and effective drug escape from the core.

Micelles delivering metallodrugs have been investigated [55-60]. One strategy involved the covalent attachment of the drug directly to the micelle to avoid its premature release in the circulation [55-59]. Sentzel's group has developed micelles to deliver Pt(II) and $\mathrm{Ru}(\mathrm{II})$ complexes to cancer cells [61-64]. They used various lengths of poly[oligo(ethylene glycol) methyl ether methacrylate] (POEGMEMA) and 1,1-di-tert-butyl 3-(2-(methacryloyloxy)ethyl) butane-1,1,3-tricarboxylate (PMAETC) block copolymers with pendant bidentate carboxylate ligands to form a carboplatin-like complex directly on the polymer [62]. The length of hydrophobic PMAETC block was varied and micelles with the shortest PMAETC block showed highest Pt(II) loading of $83 \%$, smallest hydrodynamic diameter of $\sim 77 \mathrm{~nm}$, faster $\mathrm{Pt}(\mathrm{II})$ release, and higher cytotoxicity towards lung cancer cells than micelles with longer PMAETC blocks. A similar approach was used to prepare ruthenium micelles of RAPTA-C $\left[\mathrm{RuCl}_{2}\right.$ (p-cymene)-(PTA)] [63]. RAPTA-C limits growth of solid tumor metastases, and its mechanism of action relies on inducing cancer cell apoptosis by triggering G2/M phase arrest. However, RAPTA-C suffers from poor delivery efficacy [65]. The amphiphilic polymers containing the water-soluble 1,3,5-phosphaadamantane (PTA) ligand were used to attach RAPTA-C [63]. The polymers were modified with fluorescein enabling in vitro evaluation of the micelle uptake by cancer cells. Encapsulation into micelles showed increased cellular uptake of RAPTA-C and a ten-fold increase in toxicity in ovarian cancer cell lines, when compared to a free drug.

\subsection{Polymeric Nanoparticles}

Poly(lactic-co-glycolic) acid (PLGA) [66] is an FDA-approved biodegradable slow-releasing polymer exhibiting a wide range of erosion times [67]. At present, many PLGA-based formulations are at the pre-clinical stage [68,69]. Recently, PLGA nanoparticles incorporating ruthenium-based

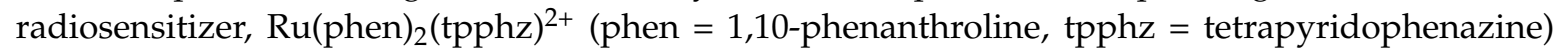
(Ru1), were investigated as a combination therapy in oesophageal cancer cells [70]. The nanoparticles were formed via a double emulsion evaporation method from a polymer:drug mixture at the ratio of $1: 6.25$, respectively, resulting in drug loading of $1.14 \%$. The surface of the nanoparticles was modified with metal ion chelator diethylenetriaminepentaacetic acid (DTPA) for ${ }^{111}$ In radiolabelling, and the targeting ligand for human epidermal growth factor receptor (EGFR). The schematic of the nanoparticle is shown in Figure 3A. The Ru1 is electron-dense and can be clearly distinguished inside the PLGA core. The in vitro studies showed higher nanoparticle uptake in EGFR-overexpressing oesophageal cancer cells, when compared to cells with normal EGFR levels. Importantly, co-delivery of ${ }^{111}$ In and Ru1 led to synergistic cytotoxic effects through ${ }^{111}$ In radiotoxicity and DNA damage fortified by $\mathbf{R u 1}$ intercalating properties, resulting in enhanced therapeutic outcomes (Figure 3B). In another approach, $\mathrm{Ru}$ (II) was encapsulated into PLGA nanoparticles with a diameter of $\sim 100 \mathrm{~nm}$ and evaluated in two-photon-excited photodynamic therapy (PDT) [71]. The nanoparticles showed cytotoxic effects in vitro on C6 glioma cells.

Yang et al. coordinated $\mathrm{Pt}$ (IV) to diamminedichlorodihydroxyplatinum (DHP) polymer or its dicarboxyl derivative diamminedichlorodisuccinatoplatinum (DSP) [72]. The platinum(IV)-polymer conjugates were easily reduced in acidic conditions producing active $\mathrm{Pt}(\mathrm{II})$ species. The constructs were cytotoxic in vitro towards breast (MDA-MB-468, MCF-7) and ovarian cancer (SKOV-3) cell lines, and in vivo evaluation showed accumulation of the conjugates in the tumor.

Earlier reports on $\mathrm{Pt}(\mathrm{IV})$ prodrugs delivery using polymeric carriers include the work of Dhar et al., where Pt(IV) complex was loaded into PEG-PLGA nanoparticles, and the nanoparticle's surface was decorated with aptamer targeting ligand for prostate-specific membrane antigen (PSMA) [73]. The in vitro studies demonstrated higher cytotoxicity of nanoparticle Pt(IV) formulation towards prostate cancer cells than the free drug. Furthermore, Aryal et al. conjugated Pt(IV) to PLA of PEG-PLA block copolymer, using acid labile bonds [74]. The nanoparticles formed from the construct had an average diameter of about $\sim 100 \mathrm{~nm}$, and showed a controlled acid-responsive drug release. 
Also, Rieter et al. synthesized the nanoparticles by precipitation of disuccinatocisplatin (DSCP) with $\mathrm{Tb}^{3+}$ ions [75]. The nanoparticles were stabilized with a shell of amorphous silica and showed higher than cisplatin in vitro cytotoxicity.
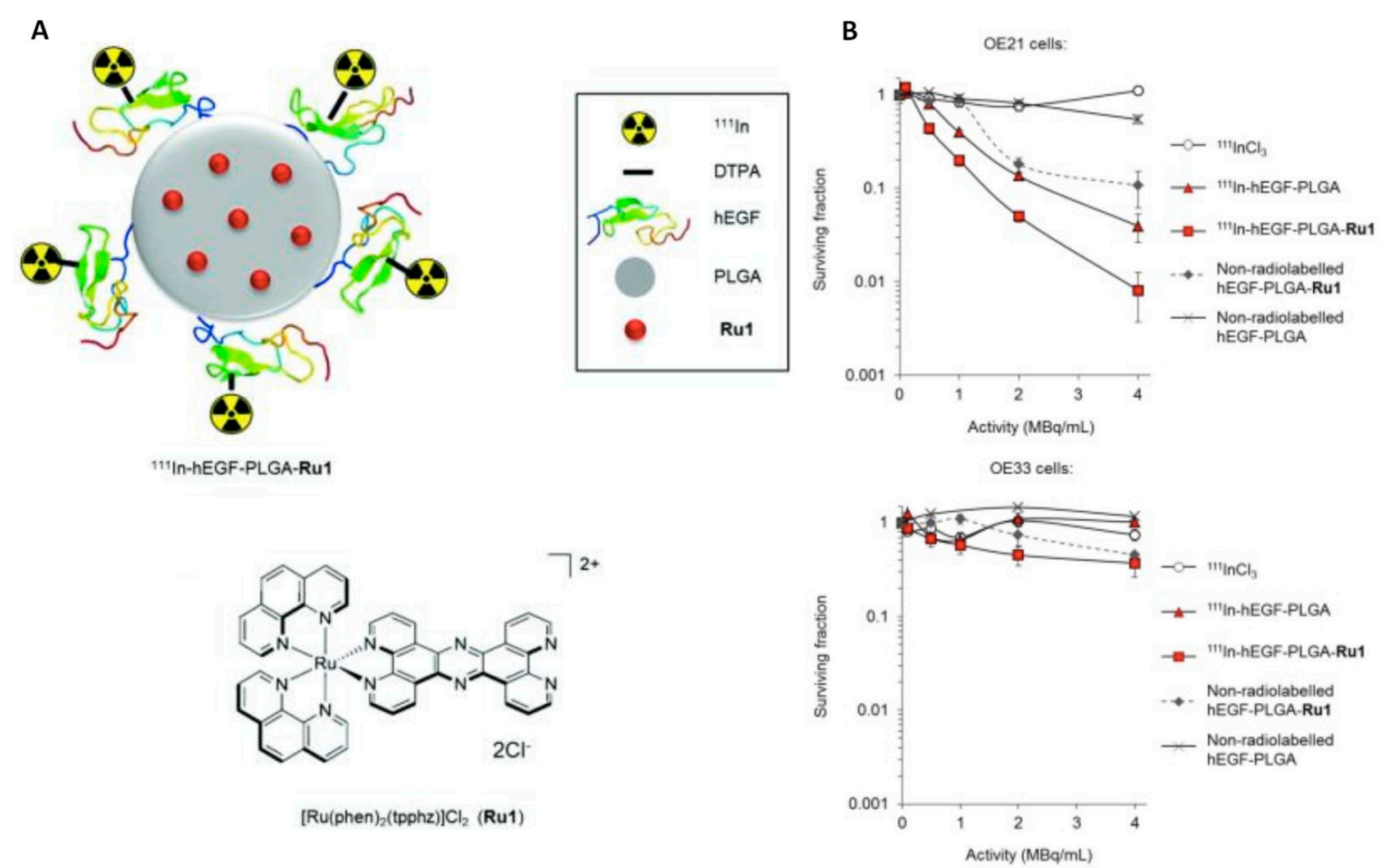

Figure 3. (A) The ruthenium(II) metallo-intercalator and radiosensitizer, Ru1, is encapsulated within Poly(lactic-co-glycolic) acid (PLGA) core and nanoparticles are surface labeled with ${ }^{111}$ In-DTPA-hEGF, bottom-chemical structure of Ru1. (B) Clonogenic survival assays of OE21 or OE33 cells exposed to ${ }^{111}$ In radiolabelled hEGF-PLGA nanoparticles with or without Ru1-loading ( $24 \mathrm{~h}$ incubation time). Non-radiolabelled nanoparticles (in equivalent concentrations; 0 to $1000 \mu \mathrm{g} \mathrm{mL}^{-1}$ ) and free ${ }^{111} \mathrm{InCl}_{3}$ (in equivalent specific activity) are included as controls. Data points are the mean of triplicates \pm S.D. Reprinted with permission from reference [70].

In another example, Keppler's group used poly(lactic acid) nanoparticles stabilized with Tween 80 surfactant, as a delivery vehicle for KP1019 [76]. The mean diameter of the nanoparticles was $164 \pm 10 \mathrm{~nm}$ with ruthenium loading of about $2.4 \mu \mathrm{mol}$ and $95 \%$ loading efficiency. The nanoparticles were stable for at least 25 days. The in vitro testing with colon carcinoma SW480 and the hepatoma Hep3B cell lines demonstrated higher cytotoxicity of the formulation versus free KP1019. Interestingly, the interaction of $\mathrm{Ru}(\mathrm{III})$ with Tween 80 led to an exchange of one chlorido ligand and reduction of $\mathrm{Ru}(\mathrm{III})$ to $\mathrm{Ru}(\mathrm{II})$, the 20-fold higher in vitro biological activity of the construct was observed.

\subsection{Carbon Nanotubes (CNTs)}

Carbon nanotubes, high aspect ratio nanomaterials, have been considered as drug delivery vehicles primarily due to their excellent cellular penetration ability, and hollow interior capable of incorporating high payloads of drug molecules. The major challenge in biological use of CNTs is their toxicity. However, large surface area of CNTs and the choice of surface chemistries can potentially alleviate this problem by introducing additional functionalities to increase biocompatibility [77].

Several carbon nanotube-based carriers have been developed for $\mathrm{Pt}(\mathrm{IV})$ prodrug delivery [78-83]. In one example, two different diameters of multi-walled carbon nanotubes were examined to deliver $\mathrm{Pt}(\mathrm{IV})$ to HeLa cells [82]. The cells internalized the CNTs-Pt effectively, with the larger diameter 
CNTs-Pt showing higher cytotoxicity than the smaller one or free drugs. Importantly, low toxicity was observed after the incubation of CNTs-Pt with murine macrophages.

Zhang et al. encapsulated ruthenium(II) complexes into single-walled carbon nanotubes for photothermal and photodynamic therapy with near-infrared (NIR) irradiation [84]. Ru(II) complexes, were sonicated with SWCNTs for $4 \mathrm{~h}$ to produce Ru@SWCNTs. The schematic of the construct and TEM image are shown in Figure 4A. Ru(II) encapsulated into SWCNTs via $\pi-\pi$ interactions, and $\mathrm{Ru}(\mathrm{II})$ loading was $15.4 \mu \mathrm{g} / \mathrm{mL}$ at SWCNTs concentration of $34.6 \mu \mathrm{g} / \mathrm{mL}$. The irradiation with an $808 \mathrm{~nm}$ diode laser led to localized photothermal effects due to light absorption by SWCNTs, while released $\mathrm{Ru}$ (II) complexes produced singlet oxygen species $\left({ }^{1} \mathrm{O}_{2}\right)$. The synergistic effect led to tumor ablation in vivo. The thermographs from the in vivo studies are shown in Figure 4B.

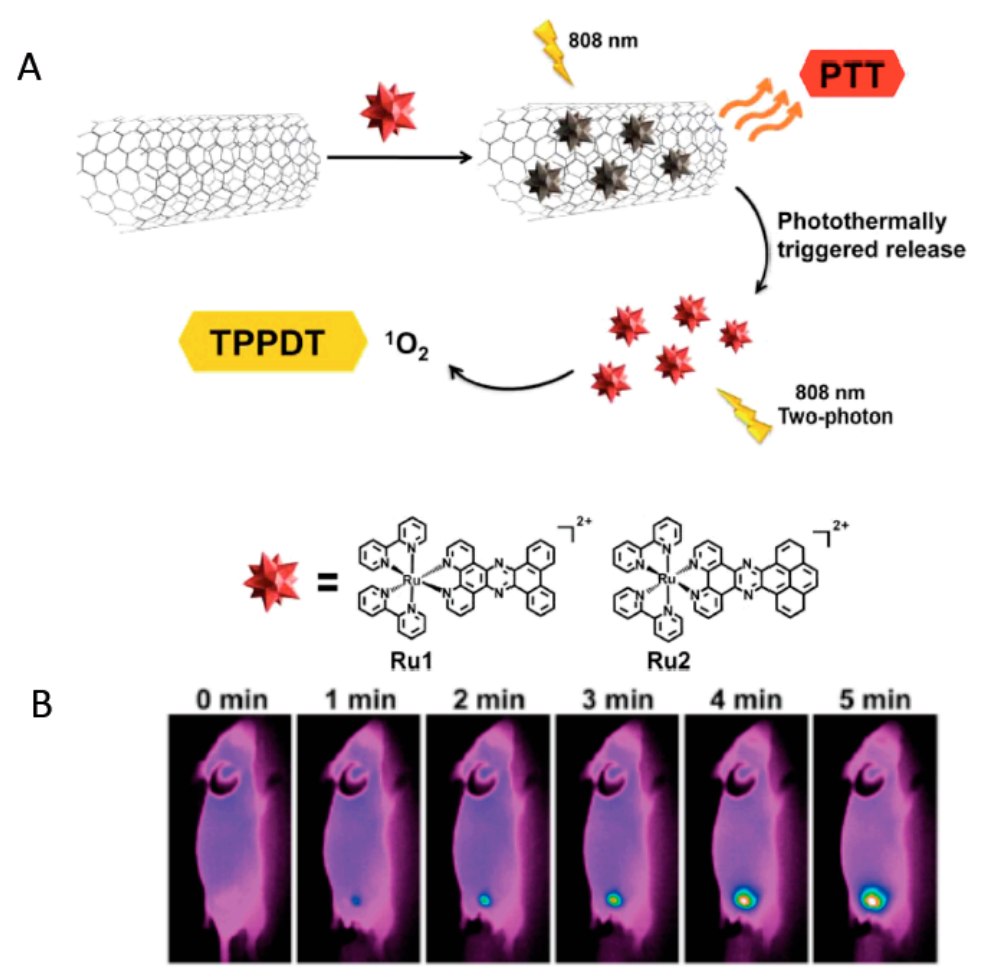

Figure 4. (A) Schematic design of Ru@SWCNTs. (B) Thermographs of tumor-bearing mice receiving photothermal treatment with Ru1@SWCNTs different periods of time (0 to $5 \mathrm{~min})$. Reprinted with permission from reference [84].

A similar approach was used by Wang et al., where a $\mathrm{Ru}(\mathrm{II})$ polypyridyl complex was loaded in multi-walled carbon nanotubes producing RuPOP@MWCNTs delivery system [85]. The cellular uptake and efficacy of the construct was evaluated in drug-resistant R-Hep-G2 liver cancer cells. The RuPOP@MWCNTs entered cells via endocytosis, and higher uptake was observed in cancer cells than in normal cells. Also, the system was evaluated with clinical X-rays, and resulted in reactive oxygen species (ROS) overproduction, which induced cancer cell apoptosis.

\subsection{Inorganic Nanoparticles}

Inorganic nanoparticles have been applied in anticancer therapy as either therapeutic agents or as carrier vehicles for small drug molecules. Their advantages include unique physicochemical properties, large surface area, and versatility of surface chemistries for ligand attachment, as well as biocompatibility [86].

Several groups have studied gold nanoparticles as a delivery system for platinum-based agents [87-91]. In one example by Xiong et al., cisplatin was complexed onto a gold nanoparticle modified with tripeptide and a folic acid-PEG linker [87]. The laser irradiation led to $\mathrm{Pt}$ (II) release 
either through the ligand exchange with chloride ions, or $\mathrm{Au}-\mathrm{S}$ bond cleavage and peptide-folate-Pt conjugate release from the surface of the nanoparticle. The cytotoxic effects were evaluated against folate-overexpressing human epidermoid carcinoma KB cells, where the nanoparticles showed high biological activity.

Pramanik et al. also used gold nanoparticles to deliver a copper(II) diacetyl-bis(N4methylthiosemicarbazone) complex [92]. The loading strategy involved the attachment of the $\mathrm{Cu}$ (II) complex to the linker containing disulfide bond in the middle and carboxylic acid end. The linker-Cu(II) was loaded onto the gold nanoparticle surface modified with the amine terminated PEG. The schematic of the nanoparticle is shown in Figure 5A. In addition, the attachment of biotin on the nanoparticle's surface provided cancer specific targeting, as fast proliferating cells demand biotin and often overexpress the biotin receptors on their surface. The in vitro and in vivo studies showed activity towards HeLa cells and a HeLa cell xenograft tumor model, respectively. The 3.8-fold reduction in tumor volume was observed with the $\mathrm{Cu}$ (II)-nanoparticle treatment (Figure 5B).

The use of selenium nanoparticles as carrier vehicles for metallodrugs has also been reported $[93,94]$. Sun et al. investigated the cytotoxicity of selenium nanoparticles stabilized with thiolated $\mathrm{Ru}(\mathrm{II})$-polypyridyl complexes [93]. The fluorescent properties of the nanoconstructs allowed the imaging studies of $\mathrm{Ru}(\mathrm{II})-\mathrm{Se}$ nanoparticle uptake by cancer cells. The $\mathrm{Ru}(\mathrm{II})-\mathrm{Se}$ nanoparticles inhibited tumor growth and angiogenesis in vivo in a xenograft HepG2 tumor model.

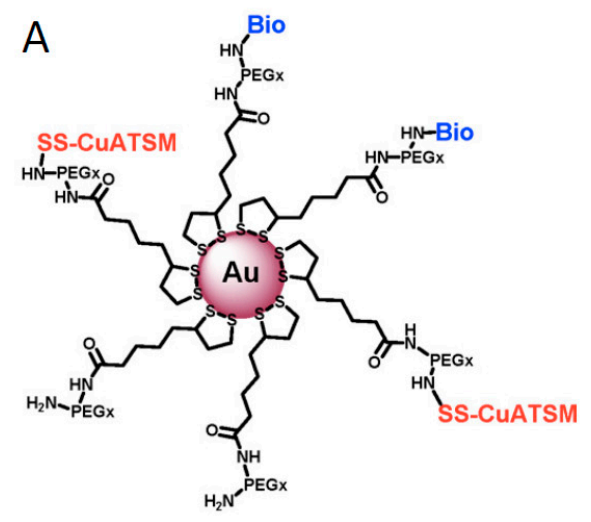

AuNP-4

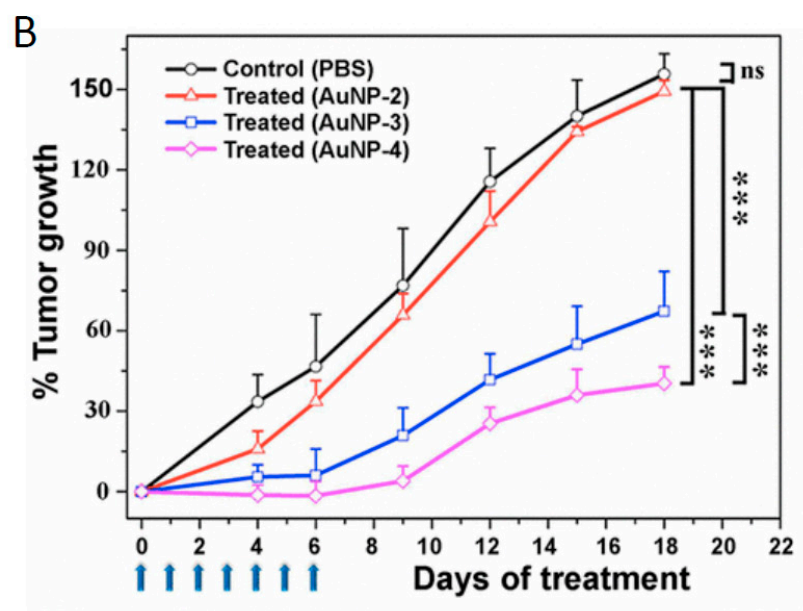

Figure 5. (A) Schematic illustration for the synthesis of PEG stabilized gold nanoparticles and nanoconjugates. (B) In vivo anticancer activity of AuNPs in mice bearing HeLa xenografts. *** indicates $p<0.001$. Reprinted with permission from reference [92].

Liu et al. synthesized folic acid-conjugated selenium nanoparticles as a carrier for ruthenium polypyridyl [94]. Similarly to previous reports, the nanoparticle was modified with folic acid for cancer cell targeting, and the system exhibited fluorescent properties allowing the imaging of the nanoparticle trafficking inside the cell. The main goal of this study was to overcome the multidrug resistance using the proposed nanoparticle system. The in vitro studies with multidrug resistant cells R-HepG2 demonstrated high toxicity through up-regulating the ROS level inside the cells triggering mitogen-activated protein kinases (MAPKs) and protein kinase B (AKT) pathways for cancer cell death.

Mesoporous silica nanoparticles also emerged as nanocarriers for metal-based complexes. The advantages of silica carriers include chemical stability, ease of surface modification with different functional groups for subsequent drug conjugation, as well as a tunable pore diameter [95]. Gomes-Ruiz's group employed mesoporous silica nanoparticles as carriers for tin, titanium, and ruthenium complexes [34,96-103]. Interestingly, they observed that the entire nanostructure of mesoporous silica-drug conjugate was involved in triggering cancer cell apoptosis, and only a small release of the encapsulated metallodrug was contributing to cytotoxic effects. This work was pioneering as it pointed towards a non-classical mechanism of action usually observed for these types 
of systems. This was highlighted in a recent publication by this group, where the complexes of tin and titanium were immobilized onto silica-based material SBA-15 (Santa Barbara Amorphous-15) modified with the aminodiol ligand 3-[bis(2-hydroxyethyl)amino] propyltriethoxysilane [102]. This construct was used as a support to attach diorganotin(IV) compound, $\mathrm{SnPh}_{2} \mathrm{Cl}_{2}$, and two titanocene derivatives, $\mathrm{TiCp}_{2} \mathrm{Cl}_{2}\left(\left[\mathrm{Ti}\left(\eta^{5}-\mathrm{C}_{5} \mathrm{H}_{5}\right)_{2} \mathrm{Cl}_{2}\right]\right.$ and $\mathrm{TiCpCpPhNfCl} 2\left(\left[\mathrm{Ti}\left(\eta^{5}-\mathrm{C}_{5} \mathrm{H}_{5}\right)\left(\eta^{5}-\mathrm{C}_{5} \mathrm{H}_{4} \mathrm{CHPhNf}\right) \mathrm{Cl}_{2}\right]\left(\mathrm{Ph}=\mathrm{C}_{6} \mathrm{H}_{5}\right.\right.$; $\mathrm{Nf}=\mathrm{C}_{10} \mathrm{H}_{7}$ ). The tin loading was determined to be $12 \mathrm{wt} \%$ and titanium 3.2 and $2.0 \mathrm{wt} \%$, respectively. The pore diameter of mesoporous silica decreased from $5.4 \mathrm{~nm}$ to $3.3 \mathrm{~nm}$ after the drug conjugation. The apoptotic effects have been studied in three different cancer cell lines: Human DLD-1 colon carcinoma, A2780 ovarian carcinoma and A431 epidermoid carcinoma. Although the observed drug release was low, only $10 \%$ of loaded tin and $1 \%$ of titanium from the constructs, the cancer cell viability was markedly reduced. It was found that silica-tin nanostructures induce apoptosis through the Fas-FasL system while silica-titanium constructs interfere with the TNF- $\alpha$ pathway. Therefore, it was concluded that the factors contributing to cancer cell death were small release of metallodrug from mesoporous silica as well as the presence of the nanoconstruct itself.

Other groups have investigated biomimetic hydroxyapatite nanocrystals as the delivery vehicles for platinum (II) [104-106]. The advantage of hydroxyapatite nanostructures is their intrinsic biocompatibility with biological systems since they are mineral constituents of bone [107]. For example, Natile's group used hydroxyapatite nanocrystals to deliver two platinum derivatives of cis-1,4-diaminocyclohexane ([PtX $\left.\mathrm{P}_{2}(\mathrm{cis}-1,4-\mathrm{DACH})\right], \mathrm{X}_{2}=\mathrm{Cl}_{2}$ and 1,1-cyclobutanedicarboxylate (CBDCA) [105]. The complexes were adsorbed on the surface of the nanocrystals and the systems were tested in different cancer cell cultures. The in vitro studies included human colon (LoVo) and lung (A549) cancer cells as well as human osteosarcoma cells sensitive (U2OS) and resistant $(\mathrm{U} 2 \mathrm{OS} / \mathrm{Pt})$ to cisplatin. The release of the complexes was accelerated at lower $\mathrm{pH}$ associated with the tumor's microenvironment, upon dissolution of hydrohyapatite nanocrystals. The hydroxyapatite-PtX $\mathrm{P}_{2}$ (cis-1,4-DACH) nanoconstruct has proven to be more cytotoxic than the other derivative, primarily due to its fast release from the nanocrystals.

\subsection{Dendrimers}

Dendrimers are nanoscale macromolecules that have a spherical three-dimensional morphology and are formed by a successive addition of layers of branching groups. The step-wise synthesis of dendrimers provides the control over the number of branches, producing different generations of the dendrimers with distinct size and molecular weight. The external layer of the dendrimer has functional groups that can provide solubility or serve as an anchoring site to attach additional ligands. The drug molecules can be encapsulated in the interior of the branches or attached to the surface groups. Dendrimers can be composed of any type of monomer, and thus a variety of dendrimers exists, with many showing low cytotoxicity profiles while applied in biological settings [108].

Dendrimers have been investigated for the delivery of metallocomplexes [109-114]. For example, Gouveia et al. produced low generation dendrimers modified with an organometallic compound of $\mathrm{Ru}(\mathrm{II})$ [110]. The nitrile poly(alkylidenimine) dendritic scaffolds of different sizes were modified with an organometallic fragment $\left[\mathrm{Ru}\left(\eta^{5}-\mathrm{C}_{5} \mathrm{H}_{5}\right)\left(\mathrm{PPh}_{3}\right)_{2}\right]^{+}$attached to the peripheral end groups of the dendrimers. $\mathrm{The} \mathrm{Ru}(\mathrm{II})$-dendrimers showed high biological activity in vitro against different cancer cell lines, such as Caco-2 (colon adenocarcinoma), CAL-72 (osteocarcoma), and MCF-7 (breast cancer). In addition, the metallodendrimers showed cytotoxicity higher than cisplatin in ovarian A2780 cells and A2780-platinum resistant cells.

In another example, Smith's group studied organometallic dendrimers of diaminobutane containing ruthenium(II)-p-cymene, ruthenium(II)-hexamethylbenzene, rhodium(III)-cyclopentadienyl, and iridium(III)-cyclopentadienyl moieties [113]. The biological activity of the metallodendrimers was evaluated in vitro using A2780 cisplatin-sensitive and A2780cisR cisplatin-resistant human ovarian cancer cell lines as well as a non-tumorigenic HEK-293 human embryonic kidney cell line. All constructs showed cytotoxicity but the most pronounced effects were observed for ferrocenyl-derived 
ruthenium(II)-hexamethylbenzene metallodendrimer. Importantly, all metallodendrimers showed lower cytotoxicity towards non-malignant cells. Interestingly, it was proposed that the possible mode of action of these constructs might involve non-covalent interactions with DNA.

Li et al. formulated supramolecular dendritic system for Pt(II) delivery (Figure 6). The building blocks included the lipoic acid functionalized dendrons, Pt(II)-PEG conjugate, and a NIR fluorophore for in vivo imaging purposes [114]. The core was bridged via disulfide bonds and incorporated Cy5.5 dye, while Pt(II)-PEG conjugate was attached to the terminal carboxyl groups of lipoic acid. $\mathrm{Pt}(\mathrm{II})$ formed carboplatin-like complex with the carboxyl groups of the acid, and PEG moiety provided the shell of the nanoplatform. The in vitro studies with lung adenocarcinoma A549 cells showed internalization of the nanostructures via endocytosis and high cytotoxicity, while in vivo studies demonstrated efficacy comparable to cisplatin with avoiding the nephrotoxicity. NIR imaging revealed the localization of nanostructures in vitro and in vivo facilitating the determination of $\mathrm{Pt}(\mathrm{II})$ delivery to target sites.

A

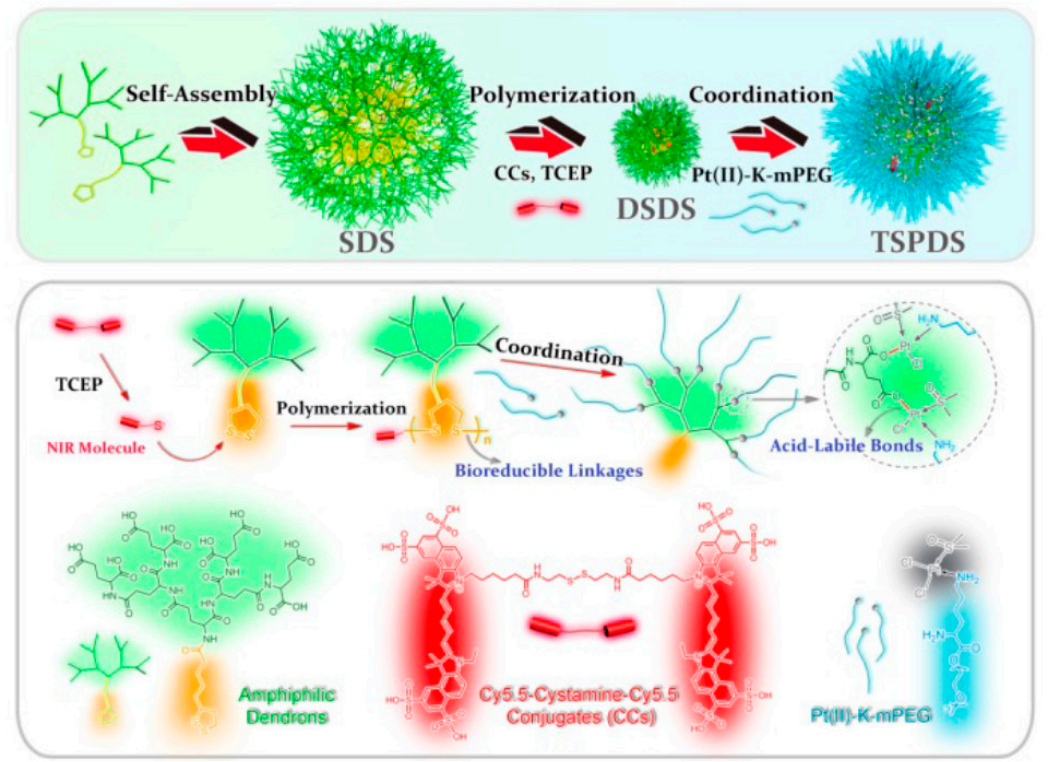

B
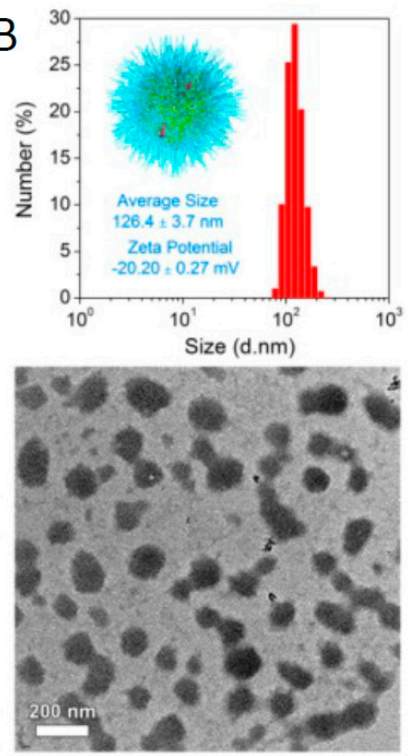

Figure 6. (A) Schematic illustrations for molecular and supramolecular engineering of theranostic supramolecular PEGylated dendritic systems. (B) Dynamic Light Scattering (DLS) results (in aqueous solutions) and TEM images for Theranostic supramolecular PEGylated dendritic systems (TSPDSs). Reprinted with permission from reference [114].

\section{Biological Carriers}

Natural biomacromolecules, such as proteins and peptides, are attractive carriers for small drug molecules due to their inherent biodegradability, biocompatibility, low toxicity, and high aqueous solubility. Additionally, biological drug carriers can recognize tumor markers overexpressed by cancer cells, which has been readily used in targeted therapies. Finally, peptides and proteins are easy to manufacture and stable, which is often challenging to accomplish with synthetic nanoparticles [115].

\subsection{Peptides}

The delivery of metallodrugs using peptides as biological carriers has been investigated. Wlodarczyk et al. used the SV40 large T antigen-derived PKKKRKV peptide known as nuclear localization sequence (NLS) peptide, as a carrier to deliver Pt(II) therapy [116]. The NLS peptide is a recognition signal on proteins facilitating the nuclear transport of biomolecules. In the study, the N-terminal of the NLS peptide was modified with malonic acid derivative during the solid-state peptide synthesis, and the carboplatin-like complex was formed directly on the peptide from activated $\mathrm{Pt}(\mathrm{II})$. The schematic of the construct is presented in Figure 7A. The solubility of the Pt-NLS hybrid 
was $50 \mathrm{mg} / \mathrm{mL}$, which was much higher than that of native carboplatin $(10 \mathrm{mg} / \mathrm{mL})$. The construct was found to effectively translocate through the cellular membrane (Figure 7B) and deliver platinum to the nucleus. Importantly, the Pt-NLS hybrid showed high biological activity in ovarian cancer cell lines, overcoming platinum resistance. This can be attributed to higher $\mathrm{Pt}(\mathrm{II})$ content in the resistant cells. The quantification of $\mathrm{Pt}(\mathrm{II})$ in the nucleus from two isogenic A2780 (Pt sensitive) and CP70 (Pt resistant) cells showed that in A2780 cells one Pt(II) was attached every 20th DNA turn, while in CP70 cells every 10th turn.

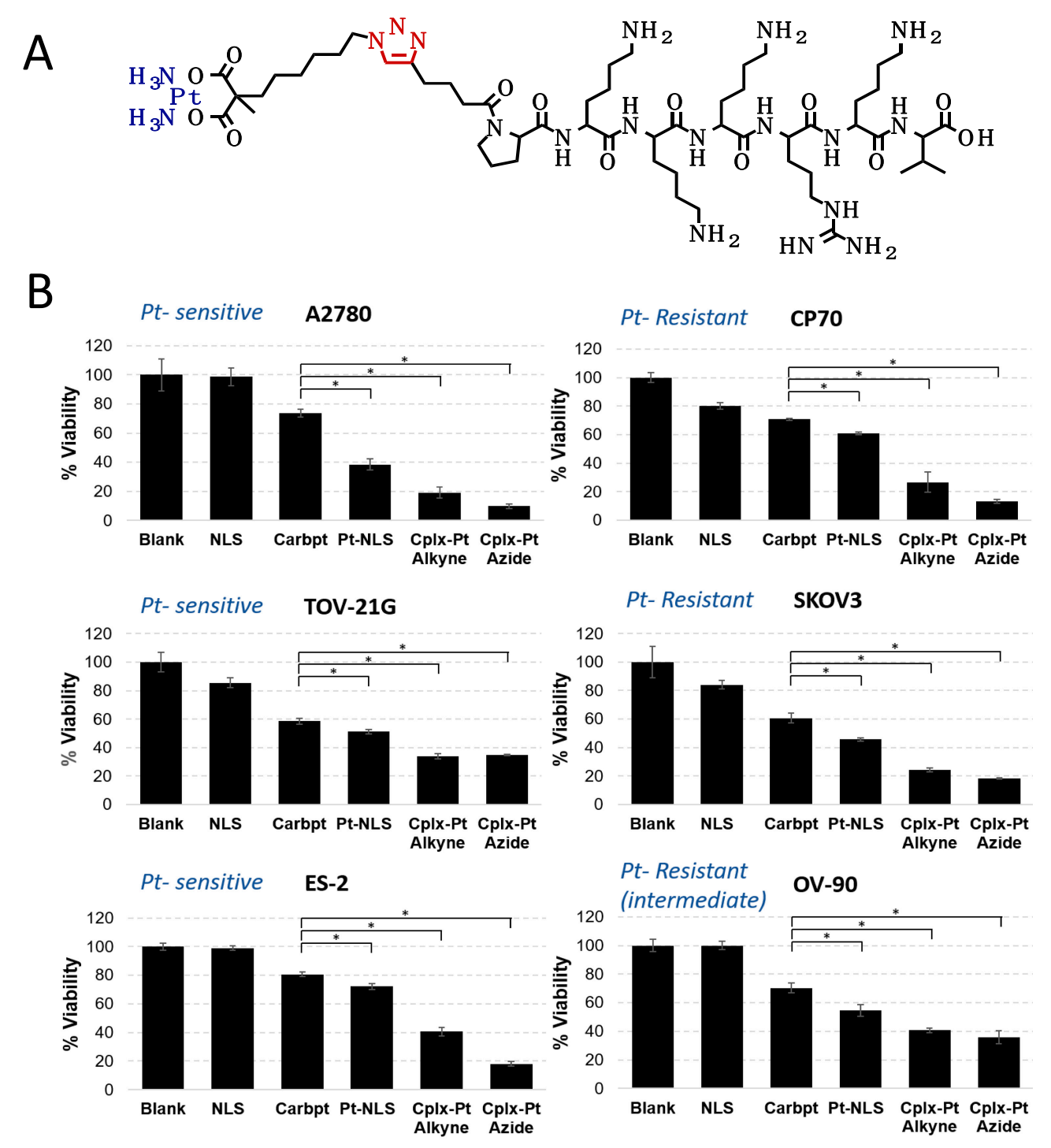

Figure 7. (A) Chemical structure of the Pt(II)- nuclear localization sequence (NLS) hybrid. (B) Viability of platinum sensitive (left) and resistant (right) cells after $72 \mathrm{~h}$ incubation with Pt-NLS hybrid and controls. * Each column represents the mean and standard deviation of $N=3$ and $p<0.005$. Reprinted with permission from reference [116].

Similarly, Noor et al. used the NLS peptide to form ferrocene-NLS conjugate [117]. The ferrocene carboxylic acid was attached to the N-terminus of the NLS peptide. The evaluation of the conjugate with Hep G2 cells did not show the cytotoxic effects. However, the presence of metallocene moiety increased the cellular uptake of the construct, which can potentially serve as a platform to add additional functionalities. The same group tested the cobaltocenium-NLS conjugates prepared using the same approach, and also observed the enhanced cellular accumulation of the construct [118]. 


\subsection{Antibodies and Proteins}

Antibody-drug conjugates (ADC) represent a highly potent class of therapeutics that combines precise cancer cell recognition by monoclonal antibodies $\mathrm{mAb}$ with cell killing by small molecule drugs. The ADC conjugates with metallodrugs have also been developed. Recently, Gupta et al. reported a $\mathrm{Pt}(\mathrm{II})$-based linker that can re-bridge the inter-chain cysteines in the antibody [119]. The schematic of the construct is shown in Figure 8A. This strategy resulted in ADC-Pt(II) constructs with higher stability than conventional ADCs connected via maleimide-based chemistry, reducing the drug exchange with blood serum albumin and off-target toxicity. The ADC-Pt(II) demonstrated high toxicity in vitro, and the in vivo studies using the A549 non-small cell lung cancer model showed marked tumor growth inhibition (Figure $8 \mathrm{~B}$ ) with up to $\sim 80 \%$ of apoptotic cells in tumor sections. This novel technology can be extended to various types of antibodies with a potential to target multiple malignancies.

Hanif et al. demonstrated the functionalization of $\mathrm{Ru}(\mathrm{II})$ (arene) complexes with maleimide. The complexes alone were characterized in vitro with human ovarian (CH1), colon (SW480), and non-small cell lung cancer (A549) cells, and showed high biological activity. The complexes were attached to thiolated biomolecules, such as Cysteine (Cys), glutathione (GSH), N-acetylcysteine (NAC), and $\mathrm{N}$-acetylcysteine methyl ester (N-AcCysMe), as well as human serum albumin (HSA) [120]. The coupling of the complexes to biomolecules was fast and was completed within $1 \mathrm{~h}$, while binding to HSA occurred in $72 \mathrm{~h}$. These results demonstrate an effective approach to attach the maleimide-modified metallodrugs to Cys-containing carrier biomolecules.

In A different approach, Zhang et al. studied the delivery of vanadocene dichloride $\left(\mathrm{Cp}_{2} \mathrm{VCl}_{2}\right)$ using human serum transferrin (h-Tf) and apotransferrin (apo-Tf) plasma proteins [121]. The transferrin protein has two Fe(III) binding sites and its primary role is to transport iron. It was demonstrated that $\mathrm{Cp}_{2} \mathrm{VCl}_{2}$ could bind with $\mathrm{h}$-Tf/apo-Tf by noncovalent conjugation at $\mathrm{pH} 7.4$ and 4.8. Moreover, the conjugates showed dose-dependent cytotoxicity towards human lung adenocarcinoma cell line A549. Interestingly, higher cytotoxicity was observed for the vanadocene-protein conjugates than for the free complex.

A

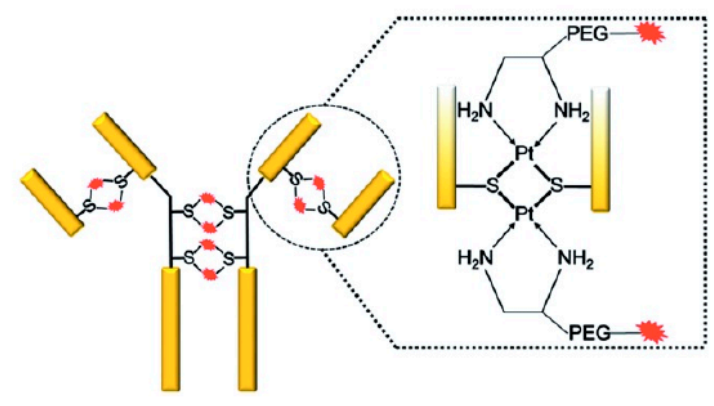

B

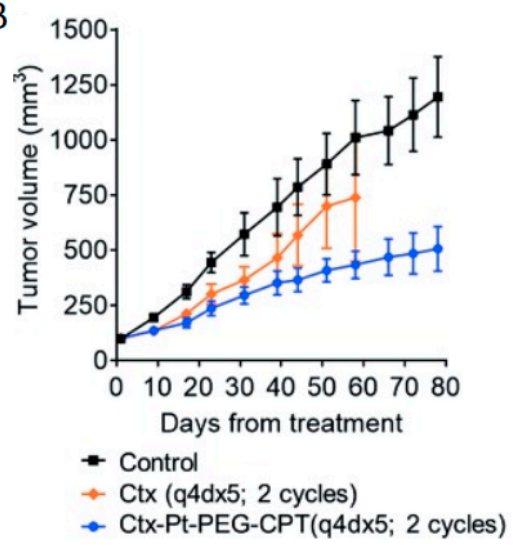

Figure 8. (A) Pt(II)-linker re-bridges the antibody chains with strong Pt-S interaction imparting stability, homogeneity and site-specificity. (B) In vivo efficacy of the Ctx-Pt-PEG-CPT treated animals showed significant differences in tumor volume compared with the control group $(p<0.016)$, with a tumor growth inhibition (TGI) of 55\%. Reprinted with permission from reference [119].

\section{Conclusions}

In summary, nanocarriers have proven to be powerful tools in enhancing the delivery of metallordrugs to cancer cells. Nanotechnology offers versatility in nanostructure synthesis methods and choice of materials, giving the control over physicochemical properties of the final nanodelivery system. This also allows encapsulating metallodrugs at sufficient payload, increasing their solubility, limiting the release in the systemic circulation preventing toxicities, and eventually heightening their efficacy 
in vivo. The main advantage of long-circulating nanocarriers is their accumulation in the tumor via EPR, which leads to increased drug payloads in the tumor. Moreover, the nanodelivery vehicles can be decorated with targeting ligands that further enhance the entry into cancer cells via receptor-mediated endocytosis. Furthermore, incorporating fluorescent dyes to the nanocarriers allows unique theranostic applications. Another attractive strategy involves conjugation of metallodrugs to biomacromolecules, such as antibodies or functional peptides. They are cheap, easy to produce, stable, and, most importantlym inherently biodegradable. Also, superior cancer cell recognition can be achieved using $\mathrm{mAb}$, which, coupled to metallodrugs, amplifies their intracellular delivery. The biological carriers might be extended even further to include vitamin-mediated drug targeting [122,123] or steroid-conjugates [124]. These systems have the potential to evolve into highly efficacious metallodrug-based therapies.

Funding: This research received no external funding.

Conflicts of Interest: The authors declare no conflicts of interest.

\section{References}

1. Oberoi, H.S.; Nukolova, N.V.; Kabanov, A.V.; Bronich, T.K. Nanocarriers for delivery of platinum anticancer drugs. Adv. Drug Deliv. Rev. 2013, 65, 1667-1685. [CrossRef] [PubMed]

2. Fichtinger-Schepman, A.M.; van Oosterom, A.T.; Lohman, P.H.; Berends, F. cis-Diamminedichloroplatinum(II)induced DNA adducts in peripheral leukocytes from seven cancer patients: Quantitative immunochemical detection of the adduct induction and removal after a single dose of cis-diamminedichloroplatinum(II). Cancer Res. 1987, 47, 3000-3004. [PubMed]

3. Englander, E.W. DNA damage response in peripheral nervous system: Coping with cancer therapy-induced DNA lesions. DNA Repair 2013, 12, 685-690. [CrossRef] [PubMed]

4. Galluzzi, L.; Senovilla, L.; Vitale, I.; Michels, J.; Martins, I.; Kepp, O.; Castedo, M.; Kroemer, G. Molecular mechanisms of cisplatin resistance. Oncogene 2012, 31, 1869-1883. [CrossRef] [PubMed]

5. Boeckman, H.J.; Trego, K.S.; Turchi, J.J. Cisplatin sensitizes cancer cells to ionizing radiation via inhibition of nonhomologous end joining. Mol. Cancer Res. MCR 2005, 3, 277-285. [CrossRef] [PubMed]

6. Aris, S.M.; Farrell, N.P. Towards Antitumor Active trans-Platinum Compounds. Eur. J. Inorg. Chem. 2009, 2009, 1293. [CrossRef]

7. Montero, E.I.; Diaz, S.; Gonzalez-Vadillo, A.M.; Perez, J.M.; Alonso, C.; Navarro-Ranninger, C. Preparation and characterization of novel trans-[PtCl(2)(amine)(isopropylamine)] compounds: Cytotoxic activity and apoptosis induction in ras-transformed cells. J. Med. Chem. 1999, 42, 4264-4268. [CrossRef]

8. Kasparkova, J.; Novakova, O.; Marini, V.; Najajreh, Y.; Gibson, D.; Perez, J.M.; Brabec, V. Activation of trans geometry in bifunctional mononuclear platinum complexes by a piperidine ligand. Mechanistic studies on antitumor action. J. Biol. Chem. 2003, 278, 47516-47525. [CrossRef]

9. Novakova, O.; Kasparkova, J.; Malina, J.; Natile, G.; Brabec, V. DNA-protein cross-linking by trans-[ $\mathrm{PtCl}_{2}(\mathrm{E}-$ iminoether $)_{2}$. A concept for activation of the trans geometry in platinum antitumor complexes. Nucleic Acids Res. 2003, 31, 6450-6460. [CrossRef]

10. Mangrum, J.B.; Farrell, N.P. Excursions in polynuclear platinum DNA binding. Chem. Commun. 2010, 46, 6640-6650. [CrossRef]

11. Kloster, M.B.; Hannis, J.C.; Muddiman, D.C.; Farrell, N. Consequences of nucleic acid conformation on the binding of a trinuclear platinum drug. Biochemistry 1999, 38, 14731-14737. [CrossRef] [PubMed]

12. Billecke, C.; Finniss, S.; Tahash, L.; Miller, C.; Mikkelsen, T.; Farrell, N.P.; Bogler, O. Polynuclear platinum anticancer drugs are more potent than cisplatin and induce cell cycle arrest in glioma. Neuro-Oncology 2006, 8, 215-226. [CrossRef] [PubMed]

13. Brabec, V.; Kasparkova, J.; Menon, V.; Farrell, N.P. Polynuclear Platinum Complexes. Structural Diversity and DNA Binding. Met. Ions Life Sci. 2018, 18. [CrossRef]

14. Malina, J.; Farrell, N.P.; Brabec, V. Substitution-Inert Polynuclear Platinum Complexes That Inhibit the Activity of DNA Polymerase in Triplex-Forming Templates. Angew. Chem. Int. Ed. Engl. 2018, 57, 8535-8539. [CrossRef] [PubMed]

15. Venkatesh, V.; Sadler, P.J. Platinum(IV) Prodrugs. Met. Ions Life Sci. 2018, 18. [CrossRef] 
16. Najjar, A.; Rajabi, N.; Karaman, R. Recent Approaches to Platinum(IV) Prodrugs: A Variety of Strategies for Enhanced Delivery and Efficacy. Curr. Pharm. Des. 2017, 23, 2366-2376. [CrossRef] [PubMed]

17. Noffke, A.L.; Habtemariam, A.; Pizarro, A.M.; Sadler, P.J. Designing organometallic compounds for catalysis and therapy. Chem. Commun. 2012, 48, 5219-5246. [CrossRef] [PubMed]

18. Liang, J.X.; Zhong, H.J.; Yang, G.; Vellaisamy, K.; Ma, D.L.; Leung, C.H. Recent development of transition metal complexes with in vivo antitumor activity. J. Inorg. Biochem. 2017, 177, 276-286. [CrossRef] [PubMed]

19. Keppler, B.K.; Friesen, C.; Vongerichten, H.; Vogel, E. Metal Complexes in Cancer Chemotherapy; VCH: Weinheim, Germany, 1993; pp. 297-323, ISBN 1-56081-216-8.

20. Hanif, M.; Hartinger, C.G. Anticancer metallodrugs: Where is the next cisplatin? Future Med. Chem. 2018, 10, 615-617. [CrossRef]

21. Alessio, E.; Messori, L. The Deceptively Similar Ruthenium(III) Drug Candidates KP1019 and NAMI-A Have Different Actions. What Did We Learn in the Past 30 Years? Met. Ions Life Sci. 2018, 18.

22. Hartinger, C.G.; Jakupec, M.A.; Zorbas-Seifried, S.; Groessl, M.; Egger, A.; Berger, W.; Zorbas, H.; Dyson, P.J.; Keppler, B.K. KP1019, a new redox-active anticancer agent-preclinical development and results of a clinical phase I study in tumor patients. Chem. Biodivers. 2008, 5, 2140-2155. [CrossRef] [PubMed]

23. Leijen, S.; Burgers, S.A.; Baas, P.; Pluim, D.; Tibben, M.; van Werkhoven, E.; Alessio, E.; Sava, G.; Beijnen, J.H.; Schellens, J.H. Phase I/II study with ruthenium compound NAMI-A and gemcitabine in patients with non-small cell lung cancer after first line therapy. Investig. New Drugs 2015, 33, 201-214. [CrossRef] [PubMed]

24. Trondl, R.; Heffeter, P.; Kowol, C.R.; Jakupec, M.A.; Berger, A.; Keppler, B.K. NKP-1339, the first ruthenium-based anticancer drug on the edge to clinical application. Chem. Sci. 2014, 5, 2925-2932. [CrossRef]

25. Antonarakis, E.S.; Emadi, A. Ruthenium-based chemotherapeutics: Are they ready for prime time? Cancer Chemother. Pharmacol. 2010, 66, 1-9. [CrossRef] [PubMed]

26. Thota, S.; Rodrigues, D.A.; Crans, D.C.; Barreiro, E.J. Ru(II) Compounds: Next-Generation Anticancer Metallotherapeutics? J. Med. Chem. 2018. [CrossRef] [PubMed]

27. Jansson, P.J.; Sharpe, P.C.; Bernhardt, P.V.; Richardson, D.R. Novel thiosemicarbazones of the ApT and DpT series and their copper complexes: Identification of pronounced redox activity and characterization of their antitumor activity. J. Med. Chem. 2010, 53, 5759-5769. [CrossRef] [PubMed]

28. Kowol, C.R.; Heffeter, P.; Miklos, W.; Gille, L.; Trondl, R.; Cappellacci, L.; Berger, W.; Keppler, B.K. Mechanisms underlying reductant-induced reactive oxygen species formation by anticancer copper(II) compounds. J. Biol. Inorg. Chem. 2012, 17, 409-423. [CrossRef]

29. Lovejoy, D.B.; Jansson, P.J.; Brunk, U.T.; Wong, J.; Ponka, P.; Richardson, D.R. Antitumor activity of metal-chelating compound Dp44mT is mediated by formation of a redox-active copper complex that accumulates in lysosomes. Cancer Res. 2011, 71, 5871-5880. [CrossRef]

30. Mirabelli, C.K.; Johnson, R.K.; Sung, C.M.; Faucette, L.; Muirhead, K.; Crooke, S.T. Evaluation of the in vivo antitumor activity and in vitro cytotoxic properties of auranofin, a coordinated gold compound, in murine tumor models. Cancer Res. 1985, 45, 32-39.

31. Van Rijt, S.H.; Romero-Canelon, I.; Fu, Y.; Shnyder, S.D.; Sadler, P.J. Potent organometallic osmium compounds induce mitochondria-mediated apoptosis and S-phase cell cycle arrest in A549 non-small cell lung cancer cells. Metallomics 2014, 6, 1014-1022. [CrossRef]

32. Kopf-Maier, P. Complexes of metals other than platinum as antitumour agents. Eur. J. Clin. Pharmacol. 1994, 47, 1-16. [CrossRef] [PubMed]

33. Lazarevic, T.; Rilak, A.; Bugarcic, Z.D. Platinum, palladium, gold and ruthenium complexes as anticancer agents: Current clinical uses, cytotoxicity studies and future perspectives. Eur. J. Med. Chem. 2017, 142, 8-31. [CrossRef] [PubMed]

34. Wani, W.A.; Prashar, S.; Shreaz, S.; Gomez-Ruiz, S. Nanostructured materials functionalized with metal complexes: In search of alternatives for administering anticancer metallodrugs. Coord. Chem. Rev. 2016, 312, 67-98. [CrossRef]

35. Sarkar, A. Novel platinum compounds and nanoparticles as anticancer agents. Pharm. Pat. Anal. 2018, 7, 33-46. [CrossRef] [PubMed]

36. Din, F.U.; Aman, W.; Ullah, I.; Qureshi, O.S.; Mustapha, O.; Shafique, S.; Zeb, A. Effective use of nanocarriers as drug delivery systems for the treatment of selected tumors. Int. J. Nanomed. 2017, 12, 7291-7309. [CrossRef] [PubMed] 
37. Malam, Y.; Loizidou, M.; Seifalian, A.M. Liposomes and nanoparticles: Nanosized vehicles for drug delivery in cancer. Trends Pharmacol. Sci. 2009, 30, 592-599. [CrossRef] [PubMed]

38. Iyer, A.K.; Khaled, G.; Fang, J.; Maeda, H. Exploiting the enhanced permeability and retention effect for tumor targeting. Drug Discov. Today 2006, 11, 812-818. [CrossRef] [PubMed]

39. Natfji, A.A.; Ravishankar, D.; Osborn, H.M.I.; Greco, F. Parameters Affecting the Enhanced Permeability and Retention Effect: The Need for Patient Selection. J. Pharm. Sci. 2017, 106, 3179-3187. [CrossRef] [PubMed]

40. Mishra, B.; Patel, B.B.; Tiwari, S. Colloidal nanocarriers: A review on formulation technology, types and applications toward targeted drug delivery. Nanomedicine 2010, 6, 9-24. [CrossRef] [PubMed]

41. Sun, T.; Zhang, Y.S.; Pang, B.; Hyun, D.C.; Yang, M.; Xia, Y. Engineered nanoparticles for drug delivery in cancer therapy. Angew. Chem. Int. Ed. Engl. 2014, 53, 12320-12364. [CrossRef] [PubMed]

42. Dragulska, S.A.; Chen, Y.; Wlodarczyk, M.T.; Poursharifi, M.; Dottino, P.; Ulijn, R.V.; Martignetti, J.A.; Mieszawska, A.J. Tripeptide-Stabilized Oil-in-Water Nanoemulsion of an Oleic Acids-Platinum(II) Conjugate as an Anticancer Nanomedicine. Bioconjugate Chem. 2018, 29, 2514-2519. [CrossRef] [PubMed]

43. Bozzuto, G.; Molinari, A. Liposomes as nanomedical devices. Int. J. Nanomed. 2015, 10, 975-999. [CrossRef] [PubMed]

44. Felice, B.; Prabhakaran, M.P.; Rodriguez, A.P.; Ramakrishna, S. Drug delivery vehicles on a nano-engineering perspective. Mater. Sci. Eng. C Mater. Biol. Appl. 2014, 41, 178-195. [CrossRef] [PubMed]

45. Fanciullino, R.; Ciccolini, J. Liposome-encapsulated anticancer drugs: Still waiting for the magic bullet? Curr. Med. Chem. 2009, 16, 4361-4371. [CrossRef] [PubMed]

46. Caster, J.M.; Patel, A.N.; Zhang, T.; Wang, A. Investigational nanomedicines in 2016: A review of nanotherapeutics currently undergoing clinical trials. Wiley Interdiscip. Rev. Nanomed. Nanobiotechnol. 2017, 9. [CrossRef] [PubMed]

47. Ventola, C.L. Progress in Nanomedicine: Approved and Investigational Nanodrugs. Pharm. Ther. 2017, 42, 742-755.

48. Boulikas, T. Clinical overview on Lipoplatin: A successful liposomal formulation of cisplatin. Expert Opin. Investig. Drugs 2009, 18, 1197-1218. [CrossRef]

49. Stathopoulos, G.P.; Boulikas, T. Lipoplatin formulation review article. J. Drug Deliv. 2012, 2012, 581363. [CrossRef]

50. Zisman, N.; Dos Santos, N.; Johnstone, S.; Tsang, A.; Bermudes, D.; Mayer, L.; Tardi, P. Optimizing Liposomal Cisplatin Efficacy through Membrane Composition Manipulations. Chemother. Res. Pract. 2011, 2011, 213848. [CrossRef]

51. Shen, J.; Kim, H.C.; Wolfram, J.; Mu, C.; Zhang, W.; Liu, H.; Xie, Y.; Mai, J.; Zhang, H.; Li, Z.; et al. A Liposome Encapsulated Ruthenium Polypyridine Complex as a Theranostic Platform for Triple-Negative Breast Cancer. Nano Lett. 2017, 17, 2913-2920. [CrossRef]

52. Rodrigues, F.P.; Carneiro, Z.A.; Mascharak, P.K.; Curti, C.; da Silva, R.S. Incorporation of a Ruthenium Nitrosyl Complex into Liposomes, the Nitric Oxide Released from these Liposomes and HepG2 Cell Death Mechanism. Coord. Chem. Rev. 2016, 306, 701-707. [CrossRef]

53. Tang, W.L.; Tang, W.H.; Li, S.D. Cancer theranostic applications of lipid-based nanoparticles. Drug Discov. Today 2018, 23, 1159-1166. [CrossRef] [PubMed]

54. Hanafy, N.A.N.; El-Kemary, M.; Leporatti, S. Micelles Structure Development as a Strategy to Improve Smart Cancer Therapy. Cancers 2018, 10, 238. [CrossRef] [PubMed]

55. Cabral, H.; Nishiyama, N.; Okazaki, S.; Koyama, H.; Kataoka, K. Preparation and biological properties of dichloro(1,2-diaminocyclohexane)platinum(II) (DACHPt)-loaded polymeric micelles. J. Control. Release 2005, 101, 223-232. [CrossRef] [PubMed]

56. Nishiyama, N.; Yokoyama, M.; Aoyagi, T.; Okano, T.; Sakurai, Y.; Kataoka, K. Preparation and Characterization of Self-Assembled Polymer-Metal Complex Micelle from cis-Dichlorodiammineplatinum(II) and Poly(ethylene glycol)-Poly( $\alpha, \beta$-aspartic acid) Block Copolymer in an Aqueous Medium. Langmuir 1999, 15, 377-383. [CrossRef]

57. Nishiyama, N.; Kataoka, K. Preparation and characterization of size-controlled polymeric micelle containing cis-dichlorodiammineplatinum(II) in the core. J. Control. Release 2001, 74, 83-94. [CrossRef]

58. Plummer, R.; Wilson, R.H.; Calvert, H.; Boddy, A.V.; Griffin, M.; Sludden, J.; Tilby, M.J.; Eatock, M.; Pearson, D.G.; Ottley, C.J.; et al. A Phase I clinical study of cisplatin-incorporated polymeric micelles (NC-6004) in patients with solid tumours. Br. J. Cancer 2011, 104, 593-598. [CrossRef] [PubMed] 
59. Bontha, S.; Kabanov, A.V.; Bronich, T.K. Polymer micelles with cross-linked ionic cores for delivery of anticancer drugs. J. Control. Release 2006, 114, 163-174. [CrossRef]

60. Heffeter, P.; Riabtseva, A.; Senkiv, Y.; Kowol, C.R.; Korner, W.; Jungwith, U.; Mitina, N.; Keppler, B.K.; Konstantinova, T.; Yanchuk, I.; et al. Nanoformulation improves activity of the (pre)clinical anticancer ruthenium complex KP1019. J. Biomed. Nanotechnol. 2014, 10, 877-884. [CrossRef]

61. Huynh, V.T.; Quek, J.Y.; de Souza, P.L.; Stenzel, M.H. Block copolymer micelles with pendant bifunctional chelator for platinum drugs: Effect of spacer length on the viability of tumor cells. Biomacromolecules 2012, 13, 1010-1023. [CrossRef]

62. Huynh, V.T.; Souza, P.; Stenzel, M.H. Polymeric Micelles with Pendant Dicarboxylato Chelating Ligands Prepared via a Michael Addition for cis-Platinum Drug Delivery. Macromolecules 2011, 44, 7888-7900. [CrossRef]

63. Blunden, B.M.; Lu, H.; Stenzel, M.H. Enhanced delivery of the RAPTA-C macromolecular chemotherapeutic by conjugation to degradable polymeric micelles. Biomacromolecules 2013, 14, 4177-4188. [CrossRef] [PubMed]

64. Lu, M.; Chen, F.; Noy, J.M.; Lu, H.; Stenzel, M.H. Enhanced Antimetastatic Activity of the Ruthenium Anticancer Drug RAPTA-C Delivered in Fructose-Coated Micelles. Macromol. Biosci. 2017, 17. [CrossRef]

65. Chatterjee, S.; Kundu, S.; Bhattacharyya, A.; Hartinger, C.G.; Dyson, P.J. The ruthenium(II)-arene compound RAPTA-C induces apoptosis in EAC cells through mitochondrial and p53-JNK pathways. J. Biol. Inorg. Chem. 2008, 13, 1149-1155. [CrossRef]

66. Zhang, L.; Chan, J.M.; Gu, F.X.; Rhee, J.W.; Wang, A.Z.; Radovic-Moreno, A.F.; Alexis, F.; Langer, R.; Farokhzad, O.C. Self-assembled lipid-polymer hybrid nanoparticles: A robust drug delivery platform. ACS Nano 2008, 2, 1696-1702. [CrossRef] [PubMed]

67. Jagur-Grodzinski, J. Biomedical application of functional polymers. React. Funct. Polym. 1999, 39, 99-138. [CrossRef]

68. Cryan, S.A. Carrier-based strategies for targeting protein and peptide drugs to the lungs. AAPS J. 2005, 7, E20-E41. [CrossRef] [PubMed]

69. Danhier, F.; Ansorena, E.; Silva, J.M.; Coco, R.; Le Breton, A.; Preat, V. PLGA-based nanoparticles: An overview of biomedical applications. J. Control. Release 2012, 161, 505-522. [CrossRef]

70. Gill, M.R.; Menon, J.U.; Jarman, P.J.; Owen, J.; Skaripa-Koukelli, I.; Able, S.; Thomas, J.A.; Carlisle, R.; Vallis, K.A. ${ }^{111}$ In-labelled polymeric nanoparticles incorporating a ruthenium-based radiosensitizer for EGFR-targeted combination therapy in oesophageal cancer cells. Nanoscale 2018, 10, 10596-10608. [CrossRef]

71. Bœuf, G.; Roullin, G.V.; Moreau, J.; Gulick, L.V.; Pineda, N.Z.; Terryn, C.; Ploton, D.; Andry, M.C.; Chuburu, F.; Dukic, S.; et al. Encapsulated Ruthenium(II) Complexes in Biocompatible Poly(D,L-lactide-co-glycolide) Nanoparticles for Application in Photodynamic Therapy. ChemPlusChem 2014, 79, 171-180. [CrossRef]

72. Yang, J.; Liu, W.; Sui, M.; Tang, J.; Shen, Y. Platinum (IV)-coordinate polymers as intracellular reductionresponsive backbone-type conjugates for cancer drug delivery. Biomaterials 2011, 32, 9136-9143. [CrossRef] [PubMed]

73. Dhar, S.; Gu, F.X.; Langer, R.; Farokhzad, O.C.; Lippard, S.J. Targeted delivery of cisplatin to prostate cancer cells by aptamer functionalized Pt(IV) prodrug-PLGA-PEG nanoparticles. Proc. Natl. Acad. Sci. USA 2008, 105, 17356-17361. [CrossRef] [PubMed]

74. Aryal, S.; Hu, C.M.; Zhang, L. Polymer-cisplatin conjugate nanoparticles for acid-responsive drug delivery. ACS Nano 2010, 4, 251-258. [CrossRef] [PubMed]

75. Rieter, W.J.; Pott, K.M.; Taylor, K.M.; Lin, W. Nanoscale coordination polymers for platinum-based anticancer drug delivery. J. Am. Chem. Soc. 2008, 130, 11584-11585. [CrossRef] [PubMed]

76. Fischer, B.; Heffeter, P.; Kryeziu, K.; Gille, L.; Meier, S.M.; Berger, W.; Kowol, C.R.; Keppler, B.K. Poly(lactic acid) nanoparticles of the lead anticancer ruthenium compound KP1019 and its surfactant-mediated activation. Dalton Trans. 2014, 43, 1096-1104. [CrossRef] [PubMed]

77. Mahajan, S.; Patharkar, A.; Kuche, K.; Maheshwari, R.; Deb, P.K.; Kalia, K.; Tekade, R.K. Functionalized carbon nanotubes as emerging delivery system for the treatment of cancer. Int. J. Pharm. 2018, 548, 540-558. [CrossRef] [PubMed]

78. Feazell, R.P.; Nakayama-Ratchford, N.; Dai, H.; Lippard, S.J. Soluble single-walled carbon nanotubes as longboat delivery systems for platinum(IV) anticancer drug design. J. Am. Chem. Soc. 2007, 129, 8438-8439. [CrossRef] [PubMed] 
79. Dhar, S.; Liu, Z.; Thomale, J.; Dai, H.; Lippard, S.J. Targeted single-wall carbon nanotube-mediated Pt(IV) prodrug delivery using folate as a homing device. J. Am. Chem. Soc. 2008, 130, 11467-11476. [CrossRef] [PubMed]

80. Yoong, S.L.; Wong, B.S.; Zhou, Q.L.; Chin, C.F.; Li, J.; Venkatesan, T.; Ho, H.K.; Yu, V.; Ang, W.H.; Pastorin, G. Enhanced cytotoxicity to cancer cells by mitochondria-targeting MWCNTs containing platinum(IV) prodrug of cisplatin. Biomaterials 2014, 35, 748-759. [CrossRef] [PubMed]

81. Li, J.; Pant, A.; Chin, C.F.; Ang, W.H.; Menard-Moyon, C.; Nayak, T.R.; Gibson, D.; Ramaprabhu, S.; Panczyk, T.; Bianco, A.; Pastorin, G. In vivo biodistribution of platinum-based drugs encapsulated into multi-walled carbon nanotubes. Nanomedicine 2014, 10, 1465-1475. [CrossRef] [PubMed]

82. Muzi, L.; Menard-Moyon, C.; Russier, J.; Li, J.; Chin, C.F.; Ang, W.H.; Pastorin, G.; Risuleo, G.; Bianco, A. Diameter-dependent release of a cisplatin pro-drug from small and large functionalized carbon nanotubes. Nanoscale 2015, 7, 5383-5394. [CrossRef]

83. Johnstone, T.C.; Suntharalingam, K.; Lippard, S.J. The Next Generation of Platinum Drugs: Targeted Pt(II) Agents, Nanoparticle Delivery, and Pt(IV) Prodrugs. Chem. Rev. 2016, 116, 3436-3486. [CrossRef] [PubMed]

84. Zhang, P.; Huang, H.; Huang, J.; Chen, H.; Wang, J.; Qiu, K.; Zhao, D.; Ji, L.; Chao, H. Noncovalent Ruthenium(II) Complexes-Single-Walled Carbon Nanotube Composites for Bimodal Photothermal and Photodynamic Therapy with Near-Infrared Irradiation. ACS Appl. Mater. Interfaces 2015, 7, 23278-23290. [CrossRef] [PubMed]

85. Wang, N.; Feng, Y.; Zeng, L.; Zhao, Z.; Chen, T. Functionalized Multiwalled Carbon Nanotubes as Carriers of Ruthenium Complexes to Antagonize Cancer Multidrug Resistance and Radioresistance. ACS Appl. Mater. Interfaces 2015, 7, 14933-14945. [CrossRef] [PubMed]

86. Wang, F.; Li, C.; Cheng, J.; Yuan, Z. Recent Advances on Inorganic Nanoparticle-Based Cancer Therapeutic Agents. Int. J. Environ. Res. Public Health 2016, 13, 1182. [CrossRef]

87. Xiong, C.; Lu, W.; Zhou, M.; Wen, X.; Li, C. Cisplatin-loaded hollow gold nanoparticles for laser-triggered release. Cancer Nanotechnol. 2018, 9, 6. [CrossRef]

88. Tan, J.; Cho, T.J.; Tsai, D.H.; Liu, J.; Pettibone, J.M.; You, R.; Hackley, V.A.; Zachariah, M.R. Surface Modification of Cisplatin-Complexed Gold Nanoparticles and Its Influence on Colloidal Stability, Drug Loading, and Drug Release. Langmuir 2018, 34, 154-163. [CrossRef] [PubMed]

89. Shi, S.; Chen, X.; Wei, J.; Huang, Y.; Weng, J.; Zheng, N. Platinum(IV) prodrug conjugated Pd@Au nanoplates for chemotherapy and photothermal therapy. Nanoscale 2016, 8, 5706-5713. [CrossRef]

90. Sánchez-Paradinas, S.; Pérez-Andrés, M.; Almendral-Parra, M.J.; Rodríguez-Fernández, E.; Millán, A.; Palacio, F.; Orfao, A.; Criado, J.J.; Fuentes, M. Enhanced cytotoxic activity of bile acid cisplatin derivatives by conjugation with gold nanoparticles. J. Inorg. Biochem. 2014, 131, 8-11. [CrossRef]

91. Shi, Y.; Goodisman, J.; Dabrowiak, J.C. Cyclodextrin capped gold nanoparticles as a delivery vehicle for a prodrug of cisplatin. Inorg. Chem. 2013, 52, 9418-9426. [CrossRef]

92. Pramanik, A.K.; Palanimuthu, D.; Somasundaram, K.; Samuelson, A.G. Biotin Decorated Gold Nanoparticles for Targeted Delivery of a Smart-Linked Anticancer Active Copper Complex: In Vitro and In Vivo Studies. Bioconjugate Chem. 2016, 27, 2874-2885. [CrossRef] [PubMed]

93. Sun, D.; Liu, Y.; Yu, Q.; Qin, X.; Yang, L.; Zhou, Y.; Chen, L.; Liu, J. Inhibition of tumor growth and vasculature and fluorescence imagingusing functionalized ruthenium-thiol protected seleniumnanoparticles. Biomaterials 2014, 35, 1572-1583. [CrossRef] [PubMed]

94. Liu, T.; Zeng, L.; Jiang, W.; Fu, Y.; Zheng, W.; Chen, T. Rational design of cancer-targeted selenium nanoparticles to antagonize multidrug resistance in cancer cells. Nanomedicine 2015, 11, 947-958. [CrossRef] [PubMed]

95. Bharti, C.; Nagaich, U.; Pal, A.K.; Gulati, N. Mesoporous silica nanoparticles in target drug delivery system: A review. Int. J. Pharm. Investig. 2015, 5, 124-133. [CrossRef] [PubMed]

96. Ellahioui, Y.; Prashar, S.; Gomez-Ruiz, S. A Short Overview on the Biomedical Applications of Silica, Alumina and Calcium Phosphate-based Nanostructured Materials. Curr. Med. Chem. 2016, 23, 4450-4467. [CrossRef] [PubMed]

97. Kaluderovic, G.N.; Perez-Quintanilla, D.; Sierra, I.; Prashar, S.; Hierro, I.; Zizak, Z.; Juranic, Z.D.; Fajardo, M.; Gomez-Ruiz, S. Study of the influence of the metal complex on the cytotoxic activity of titanocene-fucntionalized mesoporous materials. J. Mater. Chem. 2010, 20, 806-814. [CrossRef] 
98. Kaluderovic, G.N.; Perez-Quintanilla, D.; Zizak, Z.; Juranic, Z.D.; Gomez-Ruiz, S. Improvement of cytotoxicity of titanocene-functionalized mesoporous materials by the increase of the titanium content. Dalton Trans. 2010, 39, 2597-2608. [CrossRef]

99. Garcia-Penas, A.; Gomez-Ruiz, S.; Perez-Quintanilla, D.; Paschke, R.; Sierra, I.; Prashar, S.; del Hierro, I.; Kaluderovic, G.N. Study of the cytotoxicity and particle action in human cancer cells of titanocenefunctionalized materials with potential application against tumors. J. Inorg. Biochem. 2012, 106, 100-110. [CrossRef]

100. Ceballos-Torres, J.; Virag, P.; Cenariu, M.; Prashar, S.; Fajardo, M.; Fischer-Fodor, E.; Gomez-Ruiz, S. Anti-cancer applications of titanocene-functionalised nanostructured systems: An insight into cell death mechanisms. Chemistry 2014, 20, 10811-10828. [CrossRef]

101. Gomez-Ruiz, S.; Garcia-Penas, A.; Prashar, S.; Rodriguez-Dieguez, A.; Fischer-Fodor, E. Anticancer applications of nanostructured silica-based materials functionalized with titanocene derivatives: Induction of cell death mechanism through TNFR1 modulation. Materials 2018, 11, 224. [CrossRef]

102. Diaz-Garcia, D.; Cenariu, D.; Perez, Y.; Cruz, P.; Del Hierro, I.; Prashar, S.; Fischer-Fodor, E.; Gomez-Ruiz, S. Modulation of the mechanism of apoptosis in cancer cell lines by treatment with silica-based nanostructured materials functionalized with different metallodrugs. Dalton Trans. 2018, 47, 12284-12299. [CrossRef] [PubMed]

103. Ellahioui, Y.; Patra, M.; Mari, C.; Kaabi, R.; Karges, J.; Gasser, G.; Gomez-Ruiz, S. Mesoporous silica nanoparticles functionalised with a photoactive ruthenium(II) complex: Exploring the formulation of a metal-based photodynamic therapy photosensitiser. Dalton Trans. 2018. [CrossRef] [PubMed]

104. Benedetti, M.; De Castro, F.; Romano, A.; Migoni, D.; Piccinni, B.; Verri, T.; Lelli, M.; Roveri, N.; Fanizzi, F.P. Adsorption of the cis- $\left[\mathrm{Pt}\left(\mathrm{NH}_{3}\right)_{2}\left(\mathrm{P}_{2} \mathrm{O}_{7}\right)\right]\left({ }^{2-}\right)$ (phosphaplatin) on hydroxyapatite nanocrystals as a smart way to selectively release activated cis-[Pt(NH3) $\left.{ }_{2} \mathrm{Cl}_{2}\right]$ (cisplatin) in tumor tissues. J. Inorg. Biochem. 2016, 157, 73-79. [CrossRef] [PubMed]

105. Lelli, M.; Roveri, N.; Marzano, C.; Hoeschele, J.D.; Curci, A.; Margiotta, N.; Gandin, V.; Natile, G. Hydroxyapatite nanocrystals as a smart, $\mathrm{pH}$ sensitive, delivery system for kiteplatin. Dalton Trans. 2016, 45, 13187-13195. [CrossRef] [PubMed]

106. Iafisco, M.; Palazzo, B.; Marchetti, M.; Margiotta, N.; Ostuni, R.; Natile, G.; Morpurgo, M.; Gandin, V.; Marzano, C.; Roveri, N. Smart delivery of antitumoral platinum complexes from biomimetic hydroxyapatite nanocrystals. J. Mater. Chem. 2009, 19, 8385-8392. [CrossRef]

107. Roveri, N.; Iafisco, M. Evolving application of biomimetic nanostructured hydroxyapatite. Nanotechnol. Sci. Appl. 2010, 3, 107-125. [CrossRef] [PubMed]

108. Abbasi, E.; Aval, S.F.; Akbarzadeh, A.; Milani, M.; Nasrabadi, H.T.; Joo, S.W.; Hanifehpour, Y.; Nejati-Koshki, K.; Pashaei-Asl, R. Dendrimers: Synthesis, applications, and properties. Nanoscale Res. Lett. 2014, 9, 247. [CrossRef] [PubMed]

109. Govender, P.; Renfrew, A.K.; Clavel, C.M.; Dyson, P.J.; Therrien, B.; Smith, G.S. Antiproliferative activity of chelating $\mathrm{N}, \mathrm{O}$ - and $\mathrm{N}, \mathrm{N}$-ruthenium(II) arene functionalised poly(propyleneimine) dendrimer scaffolds. Dalton Trans. 2011, 40, 1158-1167. [CrossRef] [PubMed]

110. Gouveia, M.; Figueira, J.; Jardim, M.G.; Castro, R.; Tomas, H.; Rissanen, K.; Rodrigues, J. Poly(alkylidenimine) Dendrimers Functionalized with the Organometallic Moiety $\left[\mathrm{Ru}\left(\eta^{5}-\mathrm{C}_{5} \mathrm{H}_{5}\right)\left(\mathrm{PPh}_{3}\right)_{2}\right]^{+}$as Promising Drugs Against Cisplatin-Resistant Cancer Cells and Human Mesenchymal Stem Cells. Molecules 2018, $23,1471$. [CrossRef]

111. Govender, P.; Sudding, L.C.; Clavel, C.M.; Dyson, P.J.; Therrien, B.; Smith, G.S. The influence of RAPTA moieties on the antiproliferative activity of peripheral-functionalised poly(salicylaldiminato) metallodendrimers. Dalton Trans. 2013, 42, 1267-1277. [CrossRef]

112. Govender, P.; Pai, S.; Schatzschneider, U.; Smith, G.S. Next generation PhotoCORMs: Polynuclear tricarbonylmanganese(I)-functionalized polypyridyl metallodendrimers. Inorg. Chem. 2013, 52, 5470-5478. [CrossRef] [PubMed]

113. Govender, P.; Riedel, T.; Dyson, P.J.; Smith, G.S. Regulating the anticancer properties of organometallic dendrimers using pyridylferrocene entities: Synthesis, cytotoxicity and DNA binding studies. Dalton Trans. 2016, 45, 9529-9539. [CrossRef] [PubMed] 
114. Li, Y.; Li, Y.; Zhang, X.; Xu, X.; Zhang, Z.; Hu, C.; He, Y.; Gu, Z. Supramolecular PEGylated Dendritic Systems as $\mathrm{pH} /$ Redox Dual-Responsive Theranostic Nanoplatforms for Platinum Drug Delivery and NIR Imaging. Theranostics 2016, 6, 1293-1305. [CrossRef] [PubMed]

115. Zhang, Y.; Sun, T.; Jiang, C. Biomacromolecules as carriers in drug delivery and tissue engineering. Acta Pharm. Sin. B 2018, 8, 34-50. [CrossRef] [PubMed]

116. Wlodarczyk, M.T.; Camacho-Vanegas, O.; Dragulska, S.A.; Jarzecki, A.A.; Dottino, P.R.; Martignetti, J.A.; Mieszawska, A.J. Platinum (II) complex-nuclear localization sequence peptide hybrid for overcoming platinum resistance in cancer therapy. ACS Biomater. Sci. Eng. 2018, 4, 463-467. [CrossRef]

117. Noor, F.; Kinscherf, R.; Bonaterra, G.A.; Walczak, S.; Wolfl, S.; Metzler-Nolte, N. Enhanced cellular uptake and cytotoxicity studies of organometallic bioconjugates of the NLS peptide in Hep G2 cells. ChemBioChem 2009, 10, 493-502. [CrossRef] [PubMed]

118. Noor, F.; Wustholz, A.; Kinscherf, R.; Metzler-Nolte, N. A cobaltocenium-peptide bioconjugate shows enhanced cellular uptake and directed nuclear delivery. Angew. Chem. 2005, 44, 2429-2432. [CrossRef]

119. Gupta, N.; Kancharla, J.; Kaushik, S.; Ansari, A.; Hossain, S.; Goyal, R.; Pandey, M.; Sivaccumar, J.; Hussain, S.; Sarkar, A.; et al. Development of a facile antibody-drug conjugate platform for increased stability and homogeneity. Chem. Sci. 2017, 8, 2387-2395. [CrossRef]

120. Hanif, M.; Nazarov, A.A.; Legin, A.; Groessl, M.; Arion, V.B.; Jakupec, M.A.; Tsybin, Y.O.; Dyson, P.J.; Keppler, B.K.; Hartinger, C.G. Maleimide-functionalised organoruthenium anticancer agents and their binding to thiol-containing biomolecules. Chem. Commun. 2012, 48, 1475-1477. [CrossRef]

121. Zhang, Y.; Xiang, J.; Liu, Y.; Zhang, X.; Tang, Y. Constructing transferrin receptor targeted drug delivery system by using doxorubicin hydrochloride and vanadocene dichloride. Bioorg. Med. Chem. Lett. 2011, 21, 5982-5986. [CrossRef]

122. Babak, M.V.; Plazuk, D.; Meier, S.M.; Arabshahi, H.J.; Reynisson, J.; Rychlik, B.; Blauz, A.; Szulc, K.; Hanif, M.; Strobl, S.; et al. Half-sandwich ruthenium(II) biotin conjugates as biological vectors to cancer cells. Chemistry 2015, 21, 5110-5117. [CrossRef] [PubMed]

123. Scrase, T.G.; Page, S.M.; Barker, P.D.; Boss, S.R. Folates are potential ligands for ruthenium compounds in vivo. Dalton Trans. 2014, 43, 8158-8161. [CrossRef] [PubMed]

124. Ruiz, J.; Rodriguez, V.; Cutillas, N.; Espinosa, A.; Hannon, M.J. A potent ruthenium(II) antitumor complex bearing a lipophilic levonorgestrel group. Inorg. Chem. 2011, 50, 9164-9171. [CrossRef] [PubMed] 